\title{
Insulin Resistance and Endometrial Cancer: Emerging Role for microRNA
}

\author{
Iwona Sidorkiewicz $^{1, *(\mathbb{D}}$, Maciej Jóźwik ${ }^{2}$, , Magdalena Niemira ${ }^{1}\left(\mathbb{C}\right.$ and Adam Krętowski ${ }^{1,3}$ (1) \\ 1 Clinical Research Centre, Medical University of Białystok, M. Skłodowskiej-Curie 24a, \\ 15-276 Białystok, Poland; magdalena.niemira@umb.edu.pl (M.N.); adamkretowski@wp.pl (A.K.) \\ 2 Department of Gynecology and Gynecologic Oncology, Medical University of Białystok, M. \\ Skłodowskiej-Curie 24a, 15-276 Białystok, Poland; jozwikmc@interia.pl \\ 3 Department of Endocrinology, Diabetology and Internal Medicine, Medical University of Białystok, M. \\ Skłodowskiej-Curie 24a, 15-276 Białystok, Poland \\ * Correspondence: iwona.sidorkiewicz@umb.edu.pl; Tel.: +48-85-831-8893
}

Received: 30 July 2020; Accepted: 7 September 2020; Published: 8 September 2020

check for updates

Simple Summary: Insulin resistance is one of the risk factors of endometrial cancer. Hyperinsulinemia can trigger many physiological effects that drive carcinogenesis, which is also modulated by epigenetic dysregulation including miRNAs expression. Our working hypothesis was that there must be a more pronounced relationship between insulin resistance and alterations in miRNA profiles of endometrial cancer patients. Consequently, this work was undertaken to better clarify this assumption. Our careful literature search indicated that miRNA could represent a potential molecular link between the metabolic alterations related to insulin resistance and endometrial cancer. Additionally, by reporting the known relationships between miRNA and both insulin resistance and endometrial cancer, we highlighted their potential role as predictive factors of future endometrial cancer in insulin resistant patients.

Abstract: Endometrial cancer (EC) remains one of the most common cancers of the female reproductive system. Epidemiological and clinical data implicate insulin resistance (IR) and its accompanying hyperinsulinemia as key factors in the development of EC. MicroRNAs (miRNAs) are short molecules of non-coding endogenous RNA that function as post-transcriptional regulators. Accumulating evidence has shown that the miRNA expression pattern is also likely to be associated with EC risk factors. The aim of this work was the verification of the relationships between IR, EC, and miRNA, and, as based on the literature data, elucidation of miRNA's potential utility for EC prevention in IR patients. The pathways affected in IR relate to the insulin receptors, insulin-like growth factors and their receptors, insulin-like growth factor binding proteins, sex hormone-binding globulin, and estrogens. Herein, we present and discuss arguments for miRNAs as a plausible molecular link between IR and EC development. Specifically, our careful literature search indicated that dysregulation of at least 13 miRNAs has been ascribed to both conditions. We conclude that there is a reasonable possibility for miRNAs to become a predictive factor of future EC in IR patients.

Keywords: adipokines; endometrial cancer; estrogens; hyperinsulinemia; insulin; insulin resistance; insulin signaling; insulin-like growth factors; microRNA

\section{Introduction}

Endometrial cancer (EC) is the most common gynecological cancer in developed countries, with annual rates continuing to increase. It is estimated that more than 60,000 new EC diagnoses and 11,000 deaths from the disease occur in the United States alone every year [1]. However, the etiology of 
this disease is still not fully understood [1,2]. EC has been generally divided into two clinical categories. The first is classified as type I, which represents the vast majority (80-90\%) of cases and is associated with a hyperplastic, low-grade, estrogen-related endometrium. It occurs primarily in obese pre-, peri-, and early postmenopausal women, and is associated with a good prognosis. Type II is characterized by a non-estrogenic, high-grade atrophic endometrium, which is also less well-differentiated. It occurs mostly in postmenopausal women and has a high risk of relapse and metastatic disease [3]. There are several histologic types of EC, and the most common endometrioid carcinoma tends to have a favorable prognosis. Other histotypes (such as serous or clear cell carcinoma) of EC are associated with a poor prognosis [4,5]. It was initially noted that type I EC generally presents an endometrioid morphology, whereas type II cancers are characterized by non-endometrioid histology, predominantly serous (Table 1). However, this classical distinction into two EC types has been challenged by long-term follow-up of patients with cancer of endometrioid histology and grades 2 and 3 of differentiation, whose survival turned out to be worse than expected [6,7]. In line with this, Setiawan et al. observed that the risk factor patterns of high-grade endometrioid tumors and type II tumors were similar [3]. Currently, only endometrioid grade 1 (well differentiated) EC is considered to be type I, with the remainder of EC cases being included into type II.

Table 1. Conventional comparison between type I and type II endometrial cancer [8-12].

\begin{tabular}{|c|c|c|}
\hline Characteristic Feature & Type I & Type II \\
\hline Frequency & $\sim 80 \%$ of cases & Up to $20 \%$ of cases \\
\hline Estrogenic status & Estrogen-dependent & Estrogen-independent \\
\hline Histology & $\begin{array}{l}\text { Mostly endometrioid } \\
\text { adenocarcinomas }\end{array}$ & Non-endometrioid carcinoma \\
\hline Precursor lesion & Atypical hyperplasia & $\begin{array}{l}\text { Endometrial intraepithelial } \\
\text { carcinoma }\end{array}$ \\
\hline Growth & Slow growth & Rapid growth \\
\hline Risk factors & $\begin{array}{c}\text { Imbalance between estrogen and } \\
\text { progesterone exposures (such as } \\
\text { the use of unopposed estrogen } \\
\text { therapy) }\end{array}$ & $\begin{array}{l}\text { Early age at menarche, low parity, } \\
\text { tobacco smoking }\end{array}$ \\
\hline Obesity & Often present & Often absent \\
\hline Type 2 diabetes mellitus & Often present & Often absent \\
\hline $\begin{array}{l}\text { Estrogen and progesterone } \\
\text { receptors }\end{array}$ & Usually ER (+), PR (+) & Usually ER (-), PR (-) \\
\hline Prognosis & Usually good prognosis & Poor prognosis \\
\hline PTEN Mutations & Yes & No \\
\hline P53 Overexpression & No & Yes \\
\hline Other Frequent Mutations & $\begin{array}{l}\text { ARID1A } \\
\text { PIK3CA } \\
\text { CTNNB1 } \\
\text { FGFR2 }\end{array}$ & $\begin{array}{l}P P P 2 R 1 A \\
\text { FBXW7 } \\
\text { HER2 }\end{array}$ \\
\hline
\end{tabular}

ARID1A: AT-Rich Interaction Domain 1A; CTNNB1: Catenin Beta 1; ER: Estrogen Receptor; FBXW7: F-Box and WD Repeat Domain-containing 7; FGFR2: Fibroblast Growth Factor Receptor 2; HER2: Human Epidermal Growth Factor Receptor 2; PIK3CA: Phosphatidylinositol-4,5-Bisphosphate 3-Kinase Catalytic Subunit Alpha; PPP2R1A: Protein Phosphatase 2 Scaffold Subunit A alpha; PR: Progesterone Receptor; PTEN: Phosphatase and tensin homolog deleted on chromosome 10; P53: Protein 53.

In 2013, The Cancer Genome Atlas (or TCGA) Research Network classification for EC applied four molecular subgroups: DNA polymerase epsilon (POLE)-mutated (ultra-mutated), microsatellite-instable (MSI-high, hypermutated), copy-number-low/protein 53 (P53)-wild-type (CNL), and copy-number-high/P53-mutant (CNH) [11]. The POLE and MSI groups suggest better prognosis of 
EC patients, and CNL and CNH groups are coupled to worse prognosis [13,14]. The implementation of this novel EC classification laid the grounds for the refined differential diagnosis of particular cancer subtypes based on molecular signatures and provided a precision approach for both research and clinical management [5]. A long-term follow-up of patients with these specific cancer subtypes is now mandatory and of utmost importance.

Although EC is generally considered to be hormone-sensitive, its development is widely considered to also be regulated by environmental and lifestyle factors. One of this cancer's risk factors is insulin resistance (IR), a prominent component in many metabolic disorders, including prediabetes, type 2 diabetes mellitus (T2DM), metabolic syndrome, and polycystic ovary syndrome (PCOS) [15-18]. IR is a condition of reduced sensitivity of insulin-responsive tissues to insulin, which leads to an increase in blood insulin and glucose concentrations. According to the International Diabetes Federation Diabetes Atlas, the global prevalence of T2DM developed from IR continues to be on the increase [19]. Hyperinsulinemia can trigger many physiological effects that drive carcinogenesis, as insulin is a major anabolic hormone that can stimulate cell proliferation [15]. Reduced receptor binding and decreased insulin receptor-mediated transduction lead to hyperinsulinemia which, in turn, triggers the deregulation of many metabolic pathways [20]. The exact molecular mechanisms linking IR and EC are still uncertain. However, the direct effect(s) on endometrial cells of insulin and insulin-like growth factors (IGFs), as well as of alterations in the mitogen-activated protein kinase (MAPK)/extracellular-signal-regulated kinase (ERK) and in the complex of phosphatidylinositol 3-kinase (P13K)-phosphatase and tensin homolog deleted on chromosome 10 (PTEN)-protein kinase B (Akt) signaling pathways, may play crucial roles [16,21,22].

Cancer development is also associated with epigenetic dysregulation, occurring at the earliest stage of cancer [23]. The most common epigenetic modifications are DNA methylation, histone methylation and acetylation, and the actions of non-coding RNAs, including microRNAs (miRNAs). All of them can regulate multiple genes and are involved in various important signaling pathways [24]. miRNAs belong to a class of highly conserved, sequence-specific, single-stranded, endogenous small non-coding RNAs, which bind to the 3' end of the target mRNAs to induce their destabilization, degradation, and/or translation inhibition [25]. Deregulation of miRNA profiles has been implicated in a variety of cellular processes, including cancer development. Therefore, miRNAs have been drawing attention for their potential usefulness as diagnostic and/or prognostic markers [26,27].

To date, numerous studies have focused on the miRNAs' role in endometrial carcinogenesis or IR, albeit no possible reciprocal interactions of miRNA and IR on EC have been taken into account [28]. Our working hypothesis was that there must be a more pronounced relationship between IR and alterations in miRNA profiles of EC patients. Consequently, this work was undertaken to better clarify this assumption. Furthermore, we discuss the known relationships between miRNA and both clinical conditions.

\section{Clinical Importance of the Association between Insulin Resistance and Dndometrial Cancer}

Generally, IR is a principal pathophysiological process that relates not only to diabetes but also to prediabetes, as well as preclinical hyperinsulinemia and dysglycemia of varied degrees. IR has been defined as the resistance of target organs to the actions of insulin so that increased concentrations of this hormone are necessary to obtain a normal biological effect [29]. Accordingly, IR is the primary cause of T2DM and occurs years before its clinical manifestation [30]. This prediabetic state plays an important role in the development and progression of some types of cancers, including breast, prostate, colorectal, and endometrial neoplasia [31]. There is accumulating evidence that the risk factors for IR are also risk factors for EC, which strongly suggests that the development of IR and EC may be parallelly promoted at the same time. A meta-analysis conducted by Saed et al. demonstrated that diabetes increases the risk of EC by $72 \%$ [32]. Another work, a meta-analysis of 16 studies ( 3 cohort and 13 case-control studies), found that diabetes is associated with a 2.1-fold increase in the relative risk for EC [33]. Notably, a higher prevalence of EC was demonstrated in non-diabetic women with IR [34]. 
Decreased serum adiponectin (a polypeptide hormone increasing the cell's insulin sensitivity and a surrogate marker for IR) concentration was found to be independently and inversely correlated with EC occurrence [35,36]. It has also been established that the EC risk increases quite shortly following the diagnosis of IR and diabetes; that is, approximately past 6 months after their detection [37]. Elevated levels of insulin in prediabetic and diabetic patients seem to affect their cancer risk rather quickly [38]. Similarly, epidemiological evidence shows that the presence of accompanying diseases substantially influences EC risk estimations [17]. For instance, the relationship between diabetes and EC incidence can be largely promoted by increased body weight [31]. In their pooled analysis of cohort studies, Stocks et al. found direct linear relationships of body mass index (BMI), blood pressure, blood glucose, triglycerides, and total cholesterol concentrations with EC risk [39]. This finding is particularly worrying in the present era of widespread overweight and obesity.

\section{Insulin Resistance as a Driving Force for Endometrial Cancer}

Over past decades, hyperinsulinemia and IR have been implicated as playing a major role in diabetes-promoted cancers. Multiple studies were able to demonstrate a direct association between IR and the incidence of EC with several biological mechanisms as a result of their common regulation by molecular factors (such as mediators of inflammation and adipokines) [40-42]. Figure 1 presents a model of links between metabolic alterations in the development of this malignancy, highlighting the roles of changes in the insulin and IGF system and mediators of inflammation.

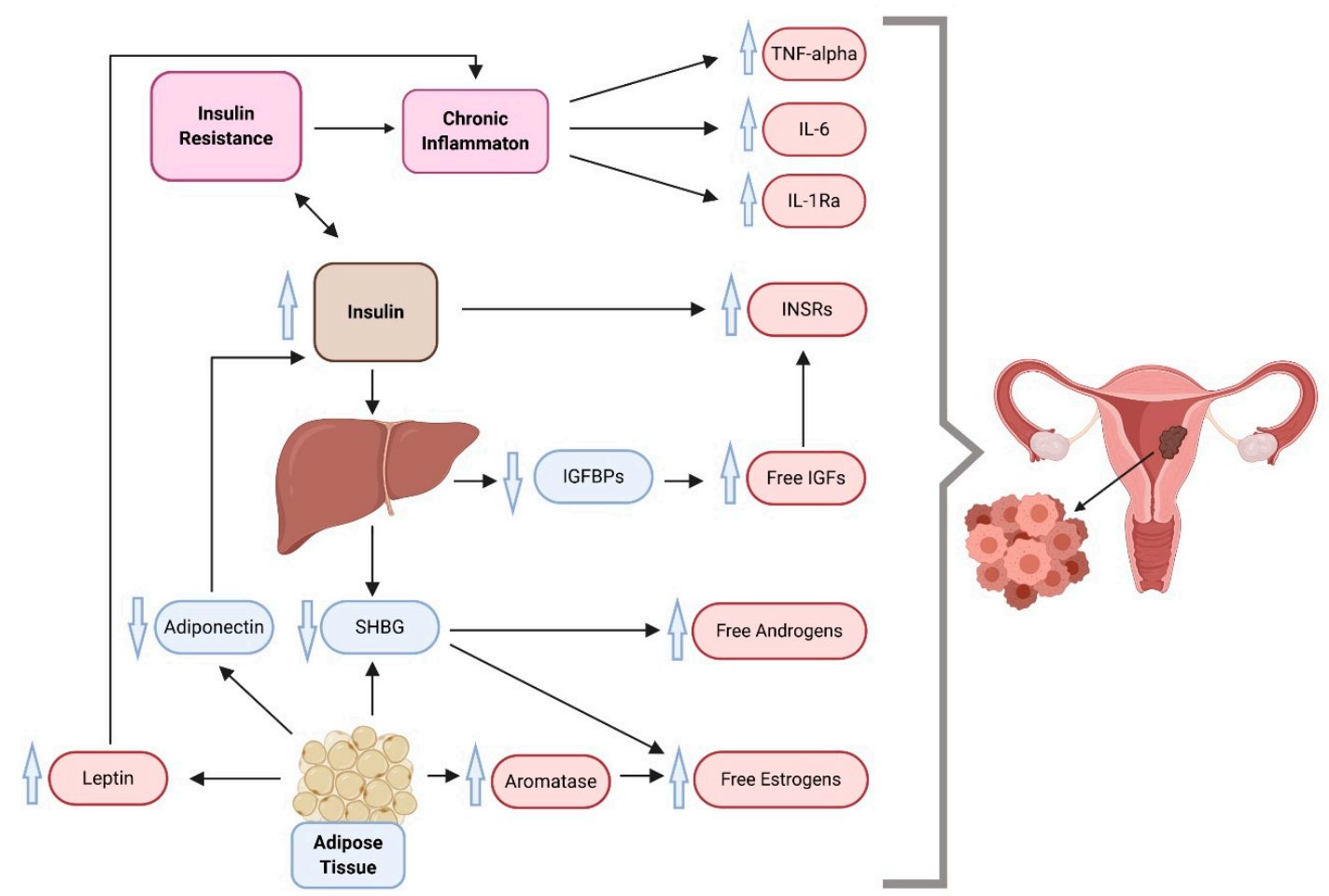

Figure 1. A proposed multidimensional model of endometrial cancer development, which suggests insulin resistance, inflammation, and overweight/obesity as driving forces behind cancer. IGFs, insulin-like growth factors; IGFBPs, insulin-like growth factor binding proteins; IL-1Ra, interleukin 1 receptor antagonist; IL-6, interleukin 6; INSR, insulin receptor; SHBG, sex hormone-binding globulin; TNF-alpha, tumor necrosis factor-alpha. Compiled from References [35,43-47].

\subsection{Insulin Receptor}

Molecular signaling downstream of insulin receptor (INSR) is tightly regulated by a large number of factors. This control system supervises energy homeostasis in peripheral target tissues for insulin. Both insulin and IGF1 activate a specific tyrosine kinase and the two main pathways of insulin signaling 
are the PI3K/Akt and the MAPK/ERK pathways. These two metabolic cascades contain several points of regulation, crosstalk with other signaling pathways, and control proliferation, differentiation, and survival at the cellular level [48,49].

Insulin signal transduction occurs through two INSR isoforms resulting from transcriptional alternative splicing: INSR-A and INSR-B, differing by the absence (INSR-A) or presence (INSR-B) of exon 11. INSR-A is the principal receptor during fetal development, recognizes both insulin and IGFs, demonstrates a greater affinity for IGF2 than IGF1, and is responsible for intracellular signaling that results in mitogenic responses. INSR-B, expressed in mature insulin-sensitive tissues, is quite insulin-specific and primarily involved in glucose homeostasis [50]. The differences in the effects exerted by INSR-A and INSR-B could be due to their varying abilities to bind IGF2 [51]. INSR-A overexpression was found in many cancer cells and tissues, suggesting that INSR-A-mediated signaling pathways may contribute to cancer pathogenesis [52]. Wang et al. demonstrated that the total INSR and INSR-A mRNA levels and the ratio of INSR-A/total INSR were significantly higher in EC than in control endometrium [53]. However, no comparisons between clinical types I and II of EC, or between particular EC histotypes, were made, making the interpretation of these results somewhat difficult. On the contrary, Flannery et al. found that INSR-B expression was increased in non-diabetic patients both in complex endometrial hyperplasia and EC, relative to normal tissue [54].

\subsection{Insulin-Like Growth Factors and Their Receptors}

Combined, insulin, IGF1, and IGF2 critically control many aspects of metabolism, growth, and survival. IGFs are predominantly produced in the liver by hepatocytes in response to growth hormone (GH) stimulation [55]. IGF1 displays significant amino acid sequence homology with insulin and enhances insulin sensitivity [56]. To date, IGF2 actions have been insufficiently characterized; however, some relevant roles have been determined for fetal development and cerebral protection [51]. Both ligands IGF1 and IGF2 activate the IGF1 receptor (IGF1R), making it their common receptor. The IGF system plays a central role in human carcinogenesis. Interestingly, it has been hypothesized that IGF2 is more closely linked to the etiology of EC than IGF1 [57].

At the pathophysiological level, insulin can also bind to IGF1R, which is a cell-surface tyrosine kinase receptor coupled to several intracellular secondary messenger pathways, including the PI3K/Akt signaling cascade. IGF1R plays a pivotal role in cell survival by regulating somatic growth, development, and metabolism, as demonstrated by using IGF1R knock-out mice that displayed severe growth deficiency, lethal neonatal lung hypoplasia, and muscle hypoplasia [58]. Although INSR and IGF1R are highly homologous and are coupled to similar intracellular pathways, insulin and IGFs stimulate distinct and specific functions, such as glucose metabolism for insulin and cell growth and proliferation for IGFs [59]. Additionally, the functional specificity of insulin/INSR signaling can be affected by: (1) crosstalk between INSR-A and IGF1 because of the abundant synthesis of INSR-A in tissues and its increased binding affinity for IGF1, (2) enhanced formation of an INSR-A/IGF1R hybrid receptor, and (3) autocrine and/or paracrine IGF production [60]. There is convincing evidence for a direct effect of insulin and IGF1 on EC cells, with the activation of the INSR resulting in both increased cell proliferation and inhibition of apoptosis [55]. From Dai et al., although serum concentrations of IGF1 and IGF2, as well as the degree of activation of IGF1R in endometrial cells did not differ between diabetic patients with or without EC, both the degree of activation of IGF2R and of PI3K were significantly higher in endometrial cells in T2DM patients with EC [61]. These same authors suggested that increased IGF2R protein expression in endometrial cells in T2DM patients could increase PI3K/cyclin D1 (CCND1)-dependent cell growth through the loss of competitive binding of IGF2 to IGF1R, a possible explanation for the higher risk of developing EC in T2DM. Moreover, this study indicated that IGF1 and IGF2 compete for binding to IGF1R, whereas binding of IGF2 to IGF1R may cause alternative phosphorylation of IGF1R with the resultant suppression of downstream PI3K and CCND1 signaling cascades [61]. Somewhat similar conclusions were obtained by Petridou et al., who suggested a more pronounced role of IGF2 than IGF1 in the etiology of EC [57]. Of clinical 
relevance, Price et al. noted that increased IGF1R expression is linked to higher BMI and better overall survival and disease-free survival in EC [62]. Gunter et al. observed that free IGF1 levels were inversely associated with the incidence of EC [63]. Of interest, Roy et al. suggested the existence of two different mechanisms that activate IGF1R in EC: ligand-dependent in type I and ligand-independent in type II [64]. These authors found that IGF1 mRNA expression was increased in type I compared with type II.

Further interesting findings were reported by Ding et al., who found that higher protein expression of IGF1, IGF1R, and INSR in colorectal cancer was associated with a history of diabetes, suggesting that IGF1/INSR signaling may play an important role in the development of this cancer in diabetic patients [65]. Unfortunately, many clinical trials with anti-IGF1R showed only limited responses in small proportions of cancer patients. Despite promising preclinical data, anti-IGF1R/INSR-targeted therapies lacked overall efficacy and the multitude of side effects led to their discontinuation $[50,66,67]$. In contrast, metformin (an oral antidiabetic drug of the biguanide family used for the treatment of T2DM) is known to interact with the IGF pathway, induces apoptosis, and inhibits proliferation and migration of EC cells [68]. Three separate systematic reviews and meta-analyses confirmed a beneficial role of metformin in improving overall survival and progression-free survival in EC [69-71]. In an in vitro study, metformin even inhibited proliferation and migration of endometrial serous carcinoma cell lines. The authors suggested that this drug could be a novel and attractive therapeutic approach for the treatment of this highly aggressive variant of EC [68].

\subsection{Insulin-Like Growth Factor Binding Proteins}

Although IGF1 is structurally related to insulin, unlike insulin, it circulates in the blood bound to specific carrier proteins, called IGF binding proteins (IGFBPs), with variable affinity. IGFBPs tightly regulate IGF1 availability by increasing its half-life, usually by forming a tertiary complex that blocks IGF1 from binding to IGF1R. Six IGFBPs (labeled IGFBP-1 to -6) have been identified so far [72]. Hyperinsulinemia has been shown to increase hepatic production and bioavailability of IGF1, in part by inhibiting hepatic production of IGFBP-1 and -2. This surplus IGF1 may excessively activate IGF1R, INSR/IGF1R, and proliferative and anti-apoptotic signaling in both premalignant and malignant tissues [45]. Insulin-sensitizing, blood pressure-lowering, and antiatherosclerotic properties of IGFBP-1 have been demonstrated, raising the possibility that increasing IGFBP-1 levels may be a therapeutic option to protect individuals from IR, arterial hypertension, and atherosclerosis [73]. However, high IGFBP-1 concentrations seem to be associated with EC risk in older women and women with an elevated BMI [74]. One study, by Weiderpass et al., found an increased risk for EC based on serum levels of IGFBP-1 solely in women who had ever used hormonal replacement therapy [75].

Recent evidence suggests beneficial effects of IGFBP-2 on systemic metabolism by indirect interacting with IGF1 signaling, including inhibition of adipogenesis and enhanced long-term insulin sensitivity [76,77]. Besides binding to IGFs, IGFBP-2 interacts with cellular components and exerts other key functions within the nucleus, directly or indirectly promoting transcriptional activation of specific genes. IGFBP-2 activities, both IGF-dependent and IGF-independent, contribute to the protein's functional roles in growth, development, metabolism, and malignancy [78]. The overexpression of IGFBP-2 has been shown to correlate with tumor progression in a number of cancers, including ovarian, lung, and pancreatic cancer [79-82]. However, the mechanisms by which IGFBP-2 contributes to the progression of cancer are still unclear [83].

As for IGFBP-3, this protein inhibits adipocyte differentiation and impacts the peroxisome proliferator-activated receptor-gamma (PPAR $\gamma$ ) system, suggesting a role for IGFBP-3 in the pathogenesis of obesity and IR. Apart from physiological IGF-dependent effects, this carrier protein has been demonstrated to regulate cell proliferation independently of binding to IGFs [84]. Mochizuki et al. found that the anti-proliferative and proapoptotic activities of IGFBP-3 are IGF-independent and attenuate epidermal growth factor (EGF)-induced EC cell proliferation. However, the exact details of action by which IGFBP-3 inhibits the EGF-mediated survival pathway require elucidation [85]. Recently, the binding of IGFBP-3 to a variety of growth factors was shown to improve the efficacy 
of anti-cancer precision therapy, counteract numerous mechanisms of tumor resistance, and combat tumor heterogeneity [86].

\subsection{Estrogens}

Estrogens are important participants in the metabolic regulation, playing a mitogenic role in the normal endometrium [87]. The effects of estrogen are mostly mediated by three receptors: two cytosolic estrogen receptors (ER), $\alpha(E R \alpha)$ and $\beta(E R \beta)$, and transmembrane $G$ protein-coupled estrogen receptor 1 (or GPER). ERs can carry out both genomic (transcription and gene expression regulation) and nongenomic (regulatory protein modifications) signal transduction. Estradiol (E2), the principal biologically active form of estrogen, controls insulin activity directly via actions on insulin-sensitive tissues or indirectly by regulating factors responsible for oxidative stress, with both outcomes contributing to IR [88]. Of note, some data suggest opposed effects of ER $\alpha$ and ER $\beta$ on glucose tolerance, and that ER $\beta$ ligands exert diabetogenic actions [89].

Estrogen signaling causes proliferation of EC [90]. Extensive crosstalk between estrogen signaling and the insulin/IGF axis was recently thoroughly discussed [91]. Research on ER-positive breast cancer (cell line MCF-7 xenografts) demonstrated that tamoxifen, a selective ER modulator, effectively inhibits classical ER-dependent transcription, including the transcription of IGF1R gene product [92]. In vivo studies have shown that E2 improves insulin sensitivity and glucose tolerance via activation of ER $\alpha /$ PI3K/Akt signaling $[93,94]$. However, E2 has been demonstrated to inhibit the in vitro binding of insulin to INSR by binding to both insulin and its receptor instead, an observation strongly suggesting the ability of E2 to induce IR either directly or indirectly [95]. Attention should be paid to tissue-specific roles of E2 [96]. Estrogens mediate the expression of IGFs in the uterus, but IGFBPs also interfere with this process $[55,97]$. Merritt et al. observed lower expression of IGF1, but higher expression of IGFBP-1 and IGFBP-3, coupled with higher protein expression for ER, INSR, and IGF1R in postmenopausal endometrium as compared to premenopausal proliferative phase endometrium [98].

Several EC risk factors provide strong support for the hypothesis of the causative role of unopposed estrogen, stating that EC risks are increased in women with high plasma estrogens and/or low progesterone, so that estrogenic effects are not sufficiently counterbalanced by the latter [99-101]. Insulin and IGF1 have been shown to stimulate ovarian steroid synthesis, resulting in cellular proliferation and inhibition of apoptosis in breast epithelium and endometrium [102]. Estrogens, both internal and from external provision, play a significant role in EC development. The majority of type I EC cases express ER, and higher ER expression has been associated with better clinical outcomes [8]. A recent analysis by Tian et al. underlined that insulin and estrogens could exert combined or even synergistic effects on the progression of type I EC [103]. Estrogens are thought to trigger proliferation and growth in cancer cells through the activation of ER $\alpha$ and the subsequent activation of PI3K and MAPK pathways [90]. Furthermore, an in vitro study showed that insulin directly stimulates aromatase activity in both endometrial glands and stroma, which strongly suggests that hyperinsulinemia caused by IR predisposes to EC by enhancing endogenous endometrial estrogen production [104]. Work by Galvão Wolff et al. indicated that IR stimulates endometrial expression of ERs and progesterone receptors (PRs), thereby contributing to the increased occurrence of endometrial proliferative lesions [105].

\subsection{Sex Hormone-Binding Globulin}

The activity of estrogens depends on their bioavailability, which is primarily determined by sex hormone-binding globulin (SHBG). The synthesis of SHBG occurs in the liver and is increased by sex steroids (mostly estrogens) and thyroxine, whereas insulin is a known important inhibitor of its production. Winters et al. found lower serum SHBG and lower hepatic SHBG expression with increasing IR, together with a weak association between fasting insulin concentration and SHBG mRNA expression [106]. Not only insulin but also IGF1 inhibits the hepatic production of SHBG [102]. 
In premenopausal women, hyperinsulinemia promotes the stimulation of ovarian androgen synthesis and decreases hepatic production of SHBG. This leads to increased circulating levels of free androgens. In contrast, in postmenopausal women, adipose tissue is the main source of estrogens through the aromatization of androgens. Obesity and hyperinsulinemia, if present, further lead to increased aromatization of androgens and decreased production of SHBG, the results of which are increased levels of bioavailable estrogen [107]. Excessive estrogens promote the development of EC, as described by the unopposed estrogen hypothesis.

\subsection{Adipokines}

The adipose tissue secretes a wide variety of bioactive molecules, including adipokines and hormones, such as adiponectin, leptin, resistin, visfatin, and chemerin, as well as proinflammatory cytokines, such as tumor necrosis factor- $\alpha$ (TNF- $\alpha$ ) [108]. Among adipokines, adiponectin proved to be particularly important. Decreased adiponectin production exerts a key role in the pathogenesis of obesity-associated disorders: arterial hypertension, metabolic syndrome, atherosclerosis, and cancer [109-111]. Two separate studies demonstrated a significant relationship between high circulating adiponectin levels and reduced EC risk, an observation largely independent of other obesity-related risk factors [112,113].

Leptin has contrasting biological functions to adiponectin: it decreases tissue sensitivity to insulin and increases plasma insulin concentration. Hyperinsulinemia and obesity are therefore linked with high leptin and low adiponectin levels [114]. The role of leptin in IR is still not fully clarified, but solid evidence indicates that leptin is a major metabolic regulator of circulating IGFBP-2 [115,116]. A relationship between serum leptin and insulin concentrations has been confirmed, regardless of body fatness [117-119]. Since obesity and adipokines are independent risk factors for EC, this notion supports the roles of two distinct mechanisms involved in endometrial carcinogenesis: excess estrogen and IR $[120,121]$. Resistance to leptin is considered a hallmark of obesity and has been shown to lead to hepatic IR [122]. Importantly, leptin plays a proinflammatory role, contributing to the generation and maintenance of low-grade inflammation, recently also linked to EC [42]. However, literature data regarding circulating levels of adiponectin and leptin in EC report conflicting results $[111,123,124]$. Increased circulating adiponectin and adiponectin/leptin ratio and decreased leptin concentration were shown to be associated with reduced risk for EC [125]. On the other hand, Ma et al. observed increased leptin and decreased adiponectin levels in EC [126]. Unfortunately, adiponectin and leptin concentrations and insulin pathway receptor expressions were not found useful for defining molecular subtypes of EC [127]. Moreover, molecular links between adipokines and cancer cells are complex and as yet, are not fully understood [128]. It has been hypothesized that circulating levels of adiponectin and leptin, together with insulin pathway molecules, exert oncogenic effects on endometrial tissue not only through their impact on the expression of tumor cell receptors but also by the activation of multiple epigenetic pathways within neoplastic cells and their microenvironment $[129,130]$.

Other adipokines/cytokines of adipose origin such as visfatin, vaspin, and omentin display proinflammatory properties and affect insulin sensitivity and secretion. Recent research indicates that serum visfatin concentration is elevated in patients with EC and that combined serum visfatin and resistin levels could be used to predict the risk of advanced stages of EC [131]. Hlavna et al. showed increased circulating levels of resistin in EC patients compared with control subjects [132]. Unraveling the pathophysiological roles of adipokines in IR and EC should be prioritized in future research [133].

\section{4. miRNAs in Both Insulin Resistance and Endometrial Cancer}

Post-transcriptional regulation by miRNAs is of interest as a mechanism to silence gene expression [134]. Aberrant expression of the miRNA profile plays a key role in a wide variety of physiological processes, including cell proliferation, apoptosis, and tissue differentiation [135]. Yet, deregulation in miRNA biogenesis and function have been shown to modulate many fundamental 
signaling pathways, including insulin synthesis, secretion, and signal transduction, and therefore, specific miRNA patterns are likely to play a role in the development of IR and related metabolic complications [136]. Importantly, miRNA-mediated insulin signaling modulation is tissue- and cell-specific, with distinct miRNAs modulating components of the insulin transduction pathway only in some tissues or cells. The basis for IR is multifactorial and includes obesity, inflammation, mitochondrial dysfunction, endoplasmic reticulum stress, oxidative stress, lipotoxicity/hyperlipidemia, genetic background, and hypoxia. These factors contribute quite differently to the disruption of insulin signaling [137].

Various conditions are caused by dysregulation of gene networks due to changes in miRNA expression, and the association between miRNAs and cancer is currently under vivid investigation [138]. miRNAs regulate cell metabolic processes either directly by targeting key molecules of metabolic pathways (transporters and enzymes, including kinases), or indirectly by modulating the expression of important transcription factors [139].

On the one hand, EC molecular subtypes have been shown to demonstrate distinct miRNA signatures. These miRNA signatures are reduced, and particular levels of depletion are characteristic for particular EC subtypes [140]. In summary, many miRNAs, either circulating or of tissue origin, have been found dysregulated in EC. Table 2 presents their comprehensive list.

Table 2. MicroRNAs (miRNAs) found as dysregulated in endometrial cancer (EC).

\begin{tabular}{|c|c|c|c|c|}
\hline miRNA & $\begin{array}{c}\text { Form of } \\
\text { Dysregulation }\end{array}$ & Studied Specimen & $\begin{array}{l}\text { Reference } \\
\text { Specimen }\end{array}$ & Reference \\
\hline $\begin{array}{l}\text { hsa-miR-1307-3p; hsa-miR-183-3p; } \\
\text { hsa-miR-183-5p; hsa-miR-200b-3p; } \\
\text { hsa-miR-429 }\end{array}$ & up & $\mathrm{EC}$ & $\begin{array}{l}\text { Normal } \\
\text { endometrium }\end{array}$ & [141] \\
\hline $\begin{array}{l}\text { hsa-miR-152-3p; hsa-miR-24-1-5p; } \\
\text { hsa-miR-374b-5p; hsa-miR-542-3p }\end{array}$ & down & $\mathrm{EC}$ & $\begin{array}{c}\text { Normal } \\
\text { endometrium }\end{array}$ & [141] \\
\hline $\begin{array}{l}\text { miR-650; miR-168; miR-572; miR-200a; } \\
\text { miR-182; miR-622; miR-34a; miR-205 }\end{array}$ & up & Endometrioid EC & $\begin{array}{c}\text { Benign } \\
\text { endometrium }\end{array}$ & [142] \\
\hline $\mathrm{miR}-411 ; \mathrm{miR}-487 \mathrm{~b}$ & down & Endometrioid EC & $\begin{array}{c}\text { Benign } \\
\text { endometrium }\end{array}$ & [142] \\
\hline $\begin{array}{l}\text { let-7c-5p; miR-125b-5p; miR-23b-3p; } \\
\text { miR-99a-5p }\end{array}$ & down & Endometrioid EC & $\begin{array}{l}\text { Non-neoplastic } \\
\text { endometrium }\end{array}$ & [143] \\
\hline $\begin{array}{c}\text { let-7g-5p; miR-195-5p; miR-34a-5p; } \\
\text { miR-497-5p }\end{array}$ & down & $\begin{array}{l}\text { Endometrioid EC } \\
\text { (grade } 1+2 \text { ) and } \\
\text { serous EC }\end{array}$ & $\begin{array}{l}\text { Non-neoplastic } \\
\text { endometrium }\end{array}$ & [143] \\
\hline $\begin{array}{l}\text { miR-205; miR-182; miR-325; miR-183; } \\
\text { miR-203; miR-210; miR-223; miR-194; } \\
\text { miR-95; miR-151; miR-200a; miR-301; } \\
\text { miR-141; miR-215; miR-103; miR-106a; } \\
\text { miR-191; miR-184; miR-326; miR-34a; } \\
\text { miR-200c; miR-23a }\end{array}$ & up & Endometrioid EC & $\begin{array}{c}\text { Normal } \\
\text { endometrium }\end{array}$ & [144] \\
\hline $\begin{array}{l}\text { miR-1; miR-101; miR-10b*; miR-127-3p; } \\
\text { miR-132*; miR-133a; miR-133b; miR-136; } \\
\text { miR-136*; miR-139-5p; miR-140-3p; } \\
\text { miR-140-5p; miR-142-3p; miR-142-5p; } \\
\text { miR-143; miR-143*; miR-145; miR-145; } \\
\text { miR-152; miR-195; miR-196b; miR-199a-5p; } \\
\text { miR-199b-3p; miR-199b-5p; miR-214; } \\
\text { miR-214*; miR-23b; miR-24-1*; miR-27b; } \\
\text { miR-299-3p; miR-299-5p; miR-29b; miR-33a; } \\
\text { miR-337-5p; miR-34b; miR-34b*; } \\
\text { miR-34c-5p; miR-376a; miR-376c; miR-377; } \\
\text { miR-379; miR-381; miR-410; miR-411; } \\
\text { miR-424; miR-450a; miR-455-3p; } \\
\text { miR-455-5p; miR-497; miR-503; miR-542-3p; } \\
\text { miR-542-5p; miR-654-3p; miR-873 }\end{array}$ & down & Serous EC & $\begin{array}{c}\text { Normal } \\
\text { endometrium }\end{array}$ & [145] \\
\hline
\end{tabular}


Table 2. Cont.

\begin{tabular}{|c|c|c|c|c|}
\hline miRNA & $\begin{array}{c}\text { Form of } \\
\text { Dysregulation }\end{array}$ & Studied Specimen & $\begin{array}{l}\text { Reference } \\
\text { Specimen }\end{array}$ & Reference \\
\hline miR-222; miR-223; miR-186; miR-204 & up & $\begin{array}{c}\text { Serum of } \\
\text { endometrioid EC } \\
\text { patients }\end{array}$ & $\begin{array}{l}\text { Serum of healthy } \\
\text { controls }\end{array}$ & [146] \\
\hline miR-186; miR-222; miR-223 & up & $\begin{array}{c}\text { Serum of EC } \\
\text { patients }\end{array}$ & $\begin{array}{l}\text { Serum of healthy } \\
\text { controls }\end{array}$ & [147] \\
\hline miR-204 & down & $\begin{array}{c}\text { Serum of EC } \\
\text { patients }\end{array}$ & $\begin{array}{l}\text { Serum of healthy } \\
\text { controls }\end{array}$ & [147] \\
\hline $\begin{array}{c}\text { let-7g*; miR-181c* miR-516a-3p; miR-9; } \\
\text { miR-203; miR-375; miR-652; miR-146a; } \\
\text { miR-9*; miR-210; miR-32; miR-148a; } \\
\text { miR-425; miR-592; miR-21; miR-7-1*; } \\
\text { miR-107 }\end{array}$ & up & Endometrioid EC & $\begin{array}{c}\text { Normal } \\
\text { endometrium }\end{array}$ & [148] \\
\hline $\begin{array}{l}\text { miR-502-3p; miR-130a; miR-214; miR-218; } \\
\text { miR-99a; miR-410; miR-100; miR-199a-3p; } \\
\text { miR-424; miR-199a-5p; miR-214*; miR-99a*; } \\
\text { let-7c; miR-212, miR-130a*; miR-495; } \\
\text { miR-100*; miR-125b*; miR-218-2*; } \\
\text { miR-502-5p; miR-532-5p }\end{array}$ & down & Endometrioid EC & $\begin{array}{c}\text { Normal } \\
\text { endometrium }\end{array}$ & [148] \\
\hline $\begin{array}{l}\text { miR-31; miR-995-5p; miR-490-3p; miR-644; } \\
\text { miR-522; miR-519d; miR-98; miR-425; } \\
\text { miR-518e; miR-155 }\end{array}$ & up & Serous EC & $\begin{array}{c}\text { Normal } \\
\text { endometrium }\end{array}$ & [148] \\
\hline miR-370; miR-423-5p & down & Serous EC & $\begin{array}{c}\text { Normal } \\
\text { endometrium }\end{array}$ & [148] \\
\hline $\begin{array}{c}\text { miR-516; let-7a; miR-424; miR-496; miR-409; } \\
\text { miR-451; miR-431; miR-516; miR-503; } \\
\text { miR-369; miR-032; miR-032b; miR-425; } \\
\text { miR-181c; miR-19b; miR-009; miR-205; } \\
\text { miR-423; miR-223; miR-183; miR-146; } \\
\text { miR-200c }\end{array}$ & up & Endometrioid EC & $\begin{array}{c}\text { Normal } \\
\text { endometrium }\end{array}$ & [149] \\
\hline
\end{tabular}

Nomenclature was given as provided by cited references. EC: endometrial cancer. *: the less expressed strand.

On the other hand, at least several miRNAs are known to be involved in the pathogenesis of cancer. As for endometrial neoplasia, a 4-miRNA signature (miR-4758, miR-876, miR-142, miR-190b) has been established as an independent prognostic factor for overall survival in EC patients (area under the curve (AUC) of receiver operating characteristic (ROC) curve was 0.7 at 5-year overall survival) [150]. By contrast, based on their systematic review, Donkers et al. proposed miR-205, the whole miR-200 family, miR-135b, miR-182, miR-183, and miR-223 as promising diagnostic biomarkers in EC [151]. Such studies were performed in the hope that the expression pattern of miRNA would become an early diagnostic and prognostic biomarker, whilst particular miRNAs could be identified as novel therapeutic targets.

Although the pathophysiology that underlies the association of IR with EC requires further investigation, miRNAs may be a missing link. Of interest, our careful literature search indicated that dysregulation of at least 13 miRNAs is actually shared by or has been ascribed to both IR and EC. Table 3 substantiates these findings.

Table 3. miRNAs found as dysregulated in both insulin resistance (IR) and EC.

\begin{tabular}{ccccc}
\hline miRNA & $\begin{array}{c}\text { Form of } \\
\text { Dysregulation }\end{array}$ & $\begin{array}{c}\text { Target Genes } \\
\text { Involved in IR }\end{array}$ & $\begin{array}{c}\text { Target Genes } \\
\text { Involved in EC }\end{array}$ & Reference \\
\hline \multirow{2}{*}{ let-7 } & down & IGF1R, IGF2BP-2, & $\begin{array}{c}\text { HMGA2, c-myc, } \\
\text { JAK, Aurora B } \\
\text { kinase, STAT3 }\end{array}$ & {$[152-154]$} \\
miR-9 & up & OC-2, SIRT1 & FOXO1 & {$[155,156]$} \\
miR-29a & up & PPARS & TPX2 & {$[157,158]$} \\
miR-29b & up & CAV2, INSIG1, & PTEN & {$[159-161]$} \\
\hline
\end{tabular}


Table 3. Cont.

\begin{tabular}{ccccc}
\hline miRNA & $\begin{array}{c}\text { Form of } \\
\text { Dysregulation }\end{array}$ & $\begin{array}{c}\text { Target Genes } \\
\text { Involved in IR }\end{array}$ & $\begin{array}{c}\text { Target Genes } \\
\text { Involved in EC }\end{array}$ & Reference \\
\hline miR-29c & down & HK2, GLUT1, IRS-1 & COL4A1 & {$[162,163]$} \\
miR-103 & up & CAV1 & TIMP-3 & {$[164,165]$} \\
miR-107 & up & CAV1 & $E R \alpha$ & {$[165,166]$} \\
miR-126 & down & $I R S-1$ & $I R S-1$ & {$[167,168]$} \\
miR-141 & up & FOXA2 & PLA2R & {$[169,170]$} \\
miR-200 & up & ZEB1 & PTEN & {$[171,172]$} \\
miR-221 & up & SIRT1 & SLUG & {$[173,174]$} \\
miR-222 & up & $I R S-1$ & $E R \alpha$ & {$[175,176]$} \\
miR-320a & up & PI3Kp85 & IGR1R & {$[177,178]$} \\
\hline
\end{tabular}

$C A V 1$, caveolin-1; CAV2, caveolin-2; ER $\alpha$, estrogen receptor alpha; FOXA2, forkhead box A2; FOXO1, forkhead transcription factor 1; GLUT1, glucose transporter 1; HK2, hexokinase 2; HMGA2, high mobility group AT-hook 2; IGFBP-2, insulin-like growth factor binding protein 2; IGF1R, insulin-like growth factor receptor; INSIG1, Insulin-Induced Gene 1; INSR, insulin receptor; IRS-1, Insulin receptor substrate 1; IRS-2, Insulin receptor substrate 2; JAK, Janus protein tyrosine kinase; OC-2, Transcription Factor Onecut-2; PI3Kp85, phosphoinositide 3-kinase regulatory subunit p85; PIK3R1, phosphatidylinositol 3-kinase regulatory subunit; PLA2R, phospholipase A2 receptor; PTEN, phosphatase and tensin homolog deleted on chromosome 10; SIRT1, Sirtuin 1; SLUG, Zinc Finger Protein SNAI2 (Snail Family Transcriptional Repressor 2); STAT3, signal transducer and activator of transcription 3; TIMP-3, tissue inhibitor of metalloproteinase 3; ZEB1, zinc finger E-box-binding homeobox 1.

The let-7 miRNA family, whose decreased expression in EC tissues has been demonstrated, is also involved in the development of IR [179]. A let-7 loss contributes to carcinogenesis via an increase in its target oncogenes (such as high-mobility group AT-hook 2 (HMGA2), c-Myc, Janus protein tyrosine kinase (JAK), Aurora B kinase, and signal transducer and activator of transcription 3 (STAT3)) and stemness factors $[153,154,180]$. However, the overexpression of let-7 in mouse skeletal muscles is related to the impairment of glucose tolerance and enhancement of IR [181]. The lin-28/let-7 axis regulates the insulin/PI3K/mammalian target of rapamycin (mTOR) pathway via multiple targets, such as IGF1R, INSR, and insulin receptor substrates 1 and 2 (IRS-1, IRS-2), thereby directly regulating glucose metabolism [152,182]. Understanding the tissue-specific regulation of let-7 may fill the current data gap and result in its potential use as a therapeutic for an array of metabolic diseases [183].

Increased expression of miR-9 in EC versus normal endometrial tissue has been shown [184-186]. Myatt et al. demonstrated that miR-9 was increased in EC tissue but lower in HEC-1B (type II EC cell line) compared with Ishikawa cells (type I EC line). Moreover, miR-9 expression was inversely correlated with forkhead transcription factor 1 (FOXO1) expression both in EC in vivo and in Ishikawa cells [155]. Two studies reported that the gene for sirtuin 1 (SIRT1), together with FOXO1 and the gene for sterol regulatory element-binding protein 1 (SREBP-1) act as a pathway involved in tumorigenesis suppression and play a role in the development of progestin resistance in EC cells $[187,188]$. Since FOXO1 and SREBP-1 are targets of insulin, their role in IR can be hypothesized. miR-9 can regulate insulin secretion by inhibiting transcription factor onecut-2 (OC-2) and SIRT1 in vivo in pancreatic $\beta$-islets [156]. In turn, this decrease in OC-2 in insulin-secreting cells results in an increase in the expression of its target gene, granuphilin, a key player in insulin secretion and known to negatively regulate insulin exocytosis [189]. mir-9 expression was first thought to be restricted to the brain and pancreatic islets, yet recent studies emphasize the need to focus on its precise functional role in cancer [190].

Members of the miR-29 family (i.e., miR-29a, b, and c) have been shown to be involved in the EC development [191]. Specifically, miR-29b was found to play important roles in proliferation and progression in EC cells by direct regulation of PTEN, whose involvement in inhibiting cell migration, invasion, and cytoskeleton rearrangement has been proven [161]. Chen et al. demonstrated that miR-29b contributes to EC angiogenesis by targeting both MAPK/ERK and PI3K/Akt signaling pathways [160]. Significant downregulation of miR-29c was observed to occur in EC, possibly resulting in increased cell proliferation and collagen type IV alpha 1 synthesis [163]. The miR-29 family is involved in IR, as its in vivo suppression in adult mice led to a significant reduction of fasting blood glucose concentration and improvement in insulin sensitivity [192]. A study by Massart et al. reported 
that miR-29a and miR-29c expression are increased in skeletal muscle from patients with T2DM, playing a pivotal role in glucose and fatty acid metabolism [162]. In line with this, silencing miR-29a resulted in decreased glucose transport and altered lipid metabolism in myotube cells, indicating the involvement of this miRNA in IR by targeting peroxisome proliferator-activated receptor $\delta(P P A R \delta)$ in skeletal muscle [157]. The various mechanisms of action by the miR-29 family suggest its dichotomous role as a tumor suppressor and oncogene based on tissue specificity $[193,194]$.

Other miRNAs involved in both IR and EC are miR-103 and miR-107. An in vitro study by $\mathrm{Du}$ et al. showed that miR-103 overexpression significantly promoted EC cell proliferation, whereas downregulation significantly suppressed EC cell proliferation [195]. miR-103 has been demonstrated to directly target tissue inhibitor of metalloproteinase 3 , leading to an imbalance between matrix metalloproteinases and their tissue inhibitors, well known to play a critical role in tumor development [164]. Hepatic miR-103 overexpression in obese mice promotes glucose intolerance and IR [165]. In turn, miR-107-5p promotes EC progression and invasion by targeting $E R \alpha$ [166]. miR-103/107 inactivation leads to increased expression of caveolin-1 (CAV1) in adipocytes, thereby reducing downstream insulin signaling and decreasing adipocyte size [165]. Interestingly, miR-103 and miR-107 target RNase III-like enzyme named DICER, which is a key component of the miRNA processing machinery, resulting in global miRNA inhibition. However, these inhibiting effects may also be mediated by other miRNAs [140].

miR-126 has been reported to directly target IRS-1 in SK-Hep1 hepatocytes [167]. This miRNA was found to be frequently downregulated in EC. Moreover, IRS-1 is involved in miR-126-mediated EC cell migration and invasion, thus raising a possibility of miR-126-based molecular targeted therapy for EC [168].

High expression of the miRNA-200 family (including miR-141, miR-200a, miR-200b, miR-200c, and miR-429) has been demonstrated in endometrioid EC compared with normal endometrium, suggestive of their substantial role in cancer growth [196]. Importantly, miR-200 has been implicated in IR by inducing pancreatic $\beta$-cell proinflammatory state and damage, and by downmodulating IRS-2 [197,198]. An in vitro study by Lu et al. showed that the expression of the miR-200 family in Ishikawa cells (type I EC cell line) was increased when compared with HEC-1B cells (type II EC line). There is convincing evidence that dynamic expression changes during transition from the normal to cancerous state reflect a link between ovarian steroids and the miRNA expression pattern [199]. Zinc finger E-box binding homeobox 1 (ZEB1) is a target gene of miR-200. The product of this gene is involved in epithelial-mesenchymal transition (EMT), which contributes to cancer invasion, metastasis, recurrence, and therapeutic resistance [200-202]. Therefore, there should be a role for miR-200 in EMT. Upregulation of miR-141 has been demonstrated in IR, as well as in EC $[169,170,196]$. The increased expression of miR-141 resulted in impaired glucose-stimulated insulin secretion and pancreatic $\beta$-cell proliferation. In addition, a positive correlation was observed in diabetic patients between miR-141 expression and blood glucose concentration. Forkhead box A2 (FOXA2) was identified as a direct miR-141 target gene [170]. Separate work demonstrated that FOXA2 must be important in tumorigenesis based on its role in the inhibition of EMT in cancer [203,204].

Interestingly, miR-221 and miR-222 are also related to both IR and EC. Ramon et al. showed a significant downregulation of miR-221/222 in endometrioid EC in comparison with control endometrium. miR-221 and -222 were negatively correlated with the vascular endothelial growth factor A (VEGF-A) protein level, an observation suggesting their involvement in the mechanism of increased VEGF-A ratios observed in EC. miR-222-3p expression was found lower in ER $\alpha$-positive EC tissues as compared with ER $\alpha$-negative ones [205]. Consequently, the level of miR-222-3p expression was lower in tumors of lower grades and earlier stages. Further, regulation of ER $\alpha$ expression by miR-222-3p was confirmed in RL95-2 EC cells [176]. Overexpression of miR-221 caused inflammation and IR in differentiated 3T3-L1 adipocytes through the suppression of SIRT1 [173]. An in vitro study on preadipocytes demonstrated that leptin and TNF- $\alpha$ downregulate miR-221, which inversely affects the adiponectin receptor 1 (ADIPOR1) and transcription factor v-ets erythroblastosis virus E26 oncogene 
homolog 1 (ETS1) expression. Adiponectin signaling promotes insulin sensitivity, and ETS1 is known to regulate the expression of cytokines, chemokines, and other genes involved in angiogenesis [206]. The association of miR-221 in the complex interplay between $E R \alpha, P R$, hypoxia-inducible factor 1-alpha (HIF1- $\alpha$ ), and zinc finger protein SNAI2 (snail family transcriptional repressor 2) (SLUG) has been demonstrated and ascribed to EMT in endometrioid EC [174].

A recent communication reported on downregulated expression of miR-320a in EC [177]. From Abbas et al., miR-320a induces proliferation inhibition in EC cells, IGF1R is a direct functional mediator for miR-320a, and IGF1R is a critical negative regulator of insulin sensitivity in the endothelium [207]. Additionally, a study by Ling et al. showed that miR-320 increases insulin sensitivity of insulin-resistant 3T3-L1 adipocytes [178]. miR-320 may inhibit insulin/PI3K signaling in adipocytes, leading to IR; thus, anti-miR-320 oligo has been proposed as a potentially new therapeutic strategy to control IR [178].

Another aspect of the EC relationship with IR is the pleiotropic function of adipokines. Adipokine-regulated miRNAs can act as either oncogenic or anti-tumoral factors [208]. Moreover, adipose tissue is a major source of circulating miRNAs and they constitute a novel class of adipokines that can act as regulators of metabolism in tissues other than fat $[209,210]$. The discovery of cell signaling mechanisms followed by the appreciation of a wide network of miRNA-target genes' expression patterns has been crucial to identify the adipokine-regulated miRNAs in the development of EC. However, the data from human patients are limited and large in vivo studies are needed [211].

It has been hypothesized that the role of miRNAs in the metabolic crosstalk is not only between cellular and non-cellular components within the tumor microenvironment but also between cancerous and other cells, such as adipocytes [174]. Another suggestion is that transfer of specific adipose cellor other cell-derived miRNAs may be involved in the regulation of endometrial tumor progression, providing a new form of intercellular communication. Overexpressed miRNAs are included in exosomes released from cells and play a functional role in cell-to-cell communication [212].

\section{Perspective and Future Directions}

Although diabetes has long been known to be an independent risk factor for EC, little is known about the relationships between IR and EC [213]. Literature data were unable to indicate clear associations between insulin, IGFs, and sex steroid hormones with EC incidence because of the multitude of dysregulated pathways that lead to EC progression. Yet, meta-analyses support the theory about the association between IR and EC. Currently, there is still a need for new precise molecular tools for the early diagnosis, risk assessment, and prediction of EC development, and miRNA may be a promising marker [214].

Epidemiological and cohort studies should determine the risk of EC in patients with IR based on miRNA expression pattern. That would allow timely intervention(s) to prevent cancer development. Patients with T2DM, prediabetes, metabolic syndrome, and PCOS should be included.

Taking into account that EC is a hormone-dependent cancer, studies on epigenetic mechanisms, including miRNA and sex steroid pathway profiling, both in cancer and IR, are worth undertaking. EC molecular subtypes have been shown to demonstrate distinct miRNA signatures [141]. These miRNA signatures are reduced, and particular levels of depletion are characteristic for particular EC subtypes [140]. A long-term follow-up of patients with these specific cancer subtypes is now mandatory to unveil the clinical significance of miRNA signatures. Similarly, long-term studies should reveal the significance of miRNAs in reference to type I and II EC. The thirteen miRNAs found by us to be dysregulated in both IR and EC are worth special attention. 


\section{Conclusions}

This review highlights changes in miRNA involved in both IR and EC. In support of the possible role of miRNA in both conditions, our careful literature search found that dysregulation of at least 13 miRNAs has been ascribed to both IR and EC. Therefore, miRNA could represent a potential molecular link between the metabolic alterations related to IR and EC. There is a reasonable possibility for miRNAs to become a predictive factor of future EC in IR patients.

Author Contributions: Conceptualization, I.S.; writing-original draft preparation, I.S.; writing-review and editing, M.J., M.N. and A.K.; visualization, I.S.; supervision, M.J. and A.K. All authors have read and agreed to the published version of the manuscript.

Funding: This research was funded by a Grant No. SUB/1/DN/20/005/1196 from the Medical University of Białystok, Poland.

Conflicts of Interest: The authors declare no conflict of interest.

\section{References}

1. Morice, P.; Leary, A.; Creutzberg, C.; Abu-Rustum, N.; Darai, E. Endometrial cancer. Lancet 2016, 387, 1094-1108. [CrossRef]

2. Memon, A.; Paudyal, P. Epidemiology of endometrial cancer. In Endometrial Cancer: Current Epidemiology, Detection and Management; Nova Science Pub Inc.: Hauppauge, NY, USA, 2014. [CrossRef]

3. Setiawan, V.W.; Yang, H.P.; Pike, M.C.; McCann, S.E.; Yu, H.; Xiang, Y.B.; Wolk, A.; Wentzensen, N.; Weiss, N.S.; Webb, P.M.; et al. Type i and II endometrial cancers: Have they different risk factors? J. Clin. Oncol. 2013, 31, 2607-2618. [CrossRef] [PubMed]

4. Burke, W.M.; Orr, J.; Leitao, M.; Salom, E.; Gehrig, P.; Olawaiye, A.B.; Brewer, M.; Boruta, D.; Villella, J.; Herzog, T.; et al. Endometrial cancer: A review and current management strategies: Part I. Gynecol. Oncol. 2014, 134, 385-392. [CrossRef] [PubMed]

5. McAlpine, J.; Leon-Castillo, A.; Bosse, T. The rise of a novel classification system for endometrial carcinoma; integration of molecular subclasses. J. Pathol. 2018, 244, 538-549. [CrossRef]

6. Voss, M.A.; Ganesan, R.; Ludeman, L.; McCarthy, K.; Gornall, R.; Schaller, G.; Wei, W.; Sundar, S. Should grade 3 endometrioid endometrial carcinoma be considered a type 2 cancer-a clinical and pathological evaluation. Gynecol. Oncol. 2012, 124, 15-20. [CrossRef]

7. Murali, R.; Soslow, R.A.; Weigelt, B. Classification of endometrial carcinoma: More than two types. Lancet Oncol. 2014, 15, e268-e278. [CrossRef]

8. Malik, T.Y.; Chishti, U.; Aziz, A.B.; Sheikh, I. Comparison of risk factors and survival of type-I and type-II endometrial cancers. Pak. J. Med. Sci. 2016, 32, 886-890. [CrossRef]

9. Amant, F.; Moerman, P.; Neven, P.; Timmerman, D.; Van Limbergen, E.; Vergote, I. Endometrial cancer. Lancet 2005, 366, 491-505. [CrossRef]

10. Remmerie, M.; Janssens, V. Targeted therapies in type II endometrial cancers: Too little, but not too late. Int. J. Mol. Sci. 2018, 19, 2380. [CrossRef] [PubMed]

11. Getz, G.; Gabriel, S.B.; Cibulskis, K.; Lander, E.; Sivachenko, A.; Sougnez, C.; Lawrence, M.; Kandoth, C.; Dooling, D.; Fulton, R.; et al. Integrated genomic characterization of endometrial carcinoma. Nature 2013, 497, 67-73. [CrossRef]

12. Raglan, O.; Kalliala, I.; Markozannes, G.; Cividini, S.; Gunter, M.J.; Nautiyal, J.; Gabra, H.; Paraskevaidis, E.; Martin-Hirsch, P.; Tsilidis, K.K.; et al. Risk factors for endometrial cancer: An umbrella review of the literature. Int. J. Cancer 2019, 145, 1719-1730. [CrossRef] [PubMed]

13. Coll-de la Rubia, E.; Martinez-Garcia, E.; Dittmar, G.; Gil-Moreno, A.; Cabrera, S.; Colas, E. Prognostic biomarkers in endometrial cancer: A systematic review and meta-analysis. J. Clin. Med. 2020, 9, 1900. [CrossRef] [PubMed]

14. León-Castillo, A.; Gilvazquez, E.; Nout, R.; Smit, V.T.H.B.M.; McAlpine, J.N.; McConechy, M.; Kommoss, S.; Brucker, S.Y.; Carlson, J.W.; Epstein, E.; et al. Clinicopathological and molecular characterisation of 'multiple-classifier' endometrial carcinomas. J. Pathol. 2020, 250, 312-322. [CrossRef] [PubMed]

15. Orgel, E.; Mittelman, S.D. The links between insulin resistance, diabetes, and cancer. Curr. Diabetes Rep. 2013, 13, 213-222. [CrossRef] [PubMed] 
16. Shafiee, M.N.; Khan, G.; Ariffin, R.; Abu, J.; Chapman, C.; Deen, S.; Nunns, D.; Barrett, D.A.; Seedhouse, C.; Atiomo, W. Preventing endometrial cancer risk in polycystic ovarian syndrome (PCOS) women: Could metformin help? Gynecol. Oncol. 2014, 132, 248-253. [CrossRef] [PubMed]

17. Kitson, S.J.; Gareth Evans, D.; Crosbie, E.J. Identifying high-risk women for endometrial cancer prevention strategies: Proposal of an endometrial cancer risk prediction model. Cancer Prev. Res. 2017, 10, 1-13. [CrossRef]

18. Mu, N.; Zhu, Y.; Wang, Y.; Zhang, H.; Xue, F. Insulin resistance: A significant risk factor of endometrial cancer. Gynecol. Oncol. 2012, 125, 751-757. [CrossRef]

19. Saeedi, P.; Petersohn, I.; Salpea, P.; Malanda, B.; Karuranga, S.; Unwin, N.; Colagiuri, S.; Guariguata, L.; Motala, A.A.; Ogurtsova, K.; et al. Global and regional diabetes prevalence estimates for 2019 and projections for 2030 and 2045: Results from the International Diabetes Federation Diabetes Atlas, 9th edition. Diabetes Res. Clin. Pract. 2019, 157, 107843. [CrossRef]

20. Thomas, D.D.; Corkey, B.E.; Istfan, N.W.; Apovian, C.M. Hyperinsulinemia: An early indicator of metabolic dysfunction. J. Endocr. Soc. 2019, 3, 1727-1747. [CrossRef]

21. Shafiee, M.N.; Chapman, C.; Barrett, D.; Abu, J.; Atiomo, W. Reviewing the molecular mechanisms which increase endometrial cancer (EC) risk in women with polycystic ovarian syndrome (PCOS): Time for paradigm shift? Gynecol. Oncol. 2013, 131, 489-492. [CrossRef]

22. Shafiee, M.N.; Seedhouse, C.; Mongan, N.; Chapman, C.; Deen, S.; Abu, J.; Atiomo, W. Up-regulation of genes involved in the insulin signalling pathway (IGF1, PTEN and IGFBP1) in the endometrium may link polycystic ovarian syndrome and endometrial cancer. Mol. Cell. Endocrinol. 2016, 424, 94-101. [CrossRef]

23. Banno, K.; Kisu, I.; Yanokura, M.; Masuda, K.; Kobayashi, Y.; Ueki, A.; Tsuji, K.; Yamagami, W.; Nomura, H.; Susumu, N.; et al. Endometrial cancer and hypermethylation: Regulation of DNA and MicroRNA by epigenetics. Biochem. Res. Int. 2012, 2012, 738274. [CrossRef]

24. Wang, H.; Peng, R.; Wang, J.; Qin, Z.; Xue, L. Circulating microRNAs as potential cancer biomarkers: The advantage and disadvantage. Clin. Epigenet. 2018, 10, 59. [CrossRef]

25. Valihrach, L.; Androvic, P.; Kubista, M. Circulating miRNA analysis for cancer diagnostics and therapy. Mol. Asp. Med. 2019, 72, 100825. [CrossRef]

26. Hayes, J.; Peruzzi, P.P.; Lawler, S. MicroRNAs in cancer: Biomarkers, functions and therapy. Trends Mol. Med. 2014, 20, 460-469. [CrossRef]

27. MacFarlane, L.-A.; Murphy, P.R. MicroRNA: Biogenesis, Function and Role in Cancer. Curr. Genom. 2010, 11, 537-561. [CrossRef]

28. Vasilatou, D.; Sioulas, V.D.; Pappa, V.; Papageorgiou, S.G.; Vlahos, N.F. The role of miRNAs in endometrial cancer. Epigenomics 2015, 7, 951-959. [CrossRef]

29. Petersen, M.C.; Shulman, G.I. Mechanisms of insulin action and insulin resistance. Physiol. Rev. 2018, 98, 2133-2223. [CrossRef]

30. Tabak, A.G.; Herder, C.; Rathman, W.; Brunner, E.J.; Kivimaki, M. Prediabetes: A high-risk state for developing diabetes. Lancet 2014, 379, 2279-2290. [CrossRef]

31. Lai, Y.; Sun, C. Association of abnormal glucose metabolism and insulin resistance in patients with atypical and typical endometrial cancer. Oncol. Lett. 2018, 15, 2173-2178. [CrossRef]

32. Saed, L.; Varse, F.; Baradaran, H.R.; Moradi, Y.; Khateri, S.; Friberg, E.; Khazaei, Z.; Gharahjeh, S.; Tehrani, S.; Sioofy-Khojine, A.B.; et al. The effect of diabetes on the risk of endometrial Cancer: An updated a systematic review and meta-analysis. BMC Cancer 2019, 19, 527. [CrossRef] [PubMed]

33. Friberg, E.; Orsini, N.; Mantzoros, C.S.; Wolk, A. Diabetes mellitus and risk of endometrial cancer: A meta-analysis. Diabetologia 2007, 50, 1365-1374. [CrossRef] [PubMed]

34. Sun, W.; Lu, J.; Wu, S.; Bi, Y.; Mu, Y.; Zhao, J.; Liu, C.; Chen, L.; Shi, L.; Li, Q.; et al. Association of insulin resistance with breast, ovarian, endometrial and cervical cancers in non-diabetic women. Am. J. Cancer Res. 2016, 6, 2334-2344. [PubMed]

35. Soliman, P.T.; Wu, D.; Tortolero-Luna, G.; Schmeler, K.M.; Slomovitz, B.M.; Bray, M.S.; Gershenson, D.M.; Lu, K.H. Association between adiponectin, insulin resistance, and endometrial cancer. Cancer 2006, 106, 1376-2381. [CrossRef] [PubMed]

36. Zeng, F.; Shi, J.; Long, Y.; Tian, H.; Li, X.; Zhao, A.Z.; Li, R.F.; Chen, T. Adiponectin and Endometrial Cancer: A Systematic Review and Meta-Analysis. Cell. Physiol. Biochem. 2015, 36, 1670-1678. [CrossRef] [PubMed] 
37. Lukanova, A.; Zeleniuch-Jacquotte, A.; Lundin, E.; Micheli, A.; Arslan, A.A.; Rinaldi, S.; Muti, P.; Lenner, P.; Koenig, K.L.; Biessy, C.; et al. Prediagnostic levels of C-peptide, IGF-I, IGFBP-1, -2 and -3 and risk of endometrial cancer. Int. J. Cancer 2004, 108, 262-268. [CrossRef]

38. Burzawa, J.K.; Schmeler, K.M.; Soliman, P.T.; Meyer, L.A.; Bevers, M.W.; Pustilnik, T.L.; Anderson, M.L.; Ramondetta, L.M.; Tortolero-Luna, G.; Urbauer, D.L.; et al. Prospective evaluation of insulin resistance among endometrial cancer patients. Am. J. Obstet. Gynecol. 2011, 204, e1-e7. [CrossRef]

39. Stocks, T.; Bjørge, T.; Ulmer, H.; Manjer, J.; Häggström, C.; Nagel, G.; Engeland, A.; Johansen, D.; Hallmans, G.; Selmer, R.; et al. Metabolic risk score and cancer risk: Pooled analysis of seven cohorts. Int. J. Epidemiol. 2015, 44, 1353-1363. [CrossRef]

40. Nead, K.T.; Sharp, S.J.; Thompson, D.J.; Painter, J.N.; Savage, D.B.; Semple, R.K.; Barker, A.; Perry, J.R.B.; Attia, J.; Dunning, A.M.; et al. Evidence of a causal sssociation between insulinemia and endometrial cancer: A mendelian randomization analysis. J. Natl. Cancer Inst. 2015, 107, djv178. [CrossRef]

41. Byrne, F.L.; Martin, A.R.; Kosasih, M.; Caruana, B.T.; Farrell, R. The role of hyperglycemia in endometrial cancer pathogenesis. Cancers Basel 2020, 12, 1191. [CrossRef]

42. Garikapati, K.K.; Ammu, V.V.V.R.K.; Krishnamurthy, P.T.; Chintamaneni, P.K.; Pindiprolu, S.K.S.S. Type-II endometrial cancer: Role of adipokines. Arch. Gynecol. Obstet. 2019, 300, 239-249. [CrossRef] [PubMed]

43. Kaya, S.; Kaya, B.; Keskin, H.L.; Kayhan Tetik, B.; Yavuz, F.A. Is there any relationship between benign endometrial pathologies and metabolic status? J. Obstet. Gynaecol. Lahore 2019, 39, 176-183. [CrossRef]

44. Dossus, L.; Rinaldi, S.; Becker, S.; Lukanova, A.; Tjonneland, A.; Olsen, A.; Stegger, J.; Overvad, K.; Chabbert-Buffet, N.; Jimenez-Corona, A.; et al. Obesity, inflammatory markers, and endometrial cancer risk: A prospective case-Control study. Endocr. Relat. Cancer 2010, 17, 1007-1019. [CrossRef] [PubMed]

45. Dossus, L.; Lukanova, A.; Rinaldi, S.; Allen, N.; Cust, A.E.; Becker, S.; Tjonneland, A.; Hansen, L.; Overvad, K.; Chabbert-Buffet, N.; et al. Hormonal, metabolic, and inflammatory profiles and endometrial cancer risk within the EPIC cohort-A factor analysis. Am. J. Epidemiol. 2013, 177, 787-799. [CrossRef]

46. Di Zazzo, E.; Polito, R.; Bartollino, S.; Nigro, E.; Porcile, C.; Bianco, A.; Daniele, A.; Moncharmont, B. Adiponectin as link factor between adipose tissue and cancer. Int. J. Mol. Sci. 2019, 20, 839. [CrossRef] [PubMed]

47. Calle, E.E.; Kaaks, R. Overweight, obesity and cancer: Epidemiological evidence and proposed mechanisms. Nat. Rev. Cancer 2004, 4, 579-591. [CrossRef]

48. Boucher, J.; Kleinridders, A.; Kahn, C.R. Insulin receptor signaling in normal and insulin-resistant states. Cold Spring Harb. Perspect. Biol. 2014, 6, a009191. [CrossRef]

49. Haeusler, R.A.; McGraw, T.E.; Accili, D. Metabolic signalling: Biochemical and cellular properties of insulin receptor signalling. Nat. Rev. Mol. Cell Biol. 2018, 19, 31-44. [CrossRef]

50. Belfiore, A.; Malaguarnera, R. Insulin receptor and cancer. Endocr. Relat. Cancer 2011, 18, R125-R147. [CrossRef]

51. Kadakia, R.; Josefson, J. The relationship of insulin-like growth factor 2 to fetal growth and adiposity. Horm. Res. Paediatr. 2016, 85, 75-82. [CrossRef]

52. Denley, A.; Wallace, J.C.; Cosgrove, L.J.; Forbes, B.E. The insulin receptor isoform exon 11-(IR-A) in cancer and other diseases: A review. Horm. Metab. Res. 2003, 35, 778-785. [CrossRef] [PubMed]

53. Wang, C.F.; Zhang, G.; Zhao, L.J.; Qi, W.J.; Li, X.P.; Wang, J.L.; Wei, L.H. Overexpression of the Insulin Receptor Isoform A Promotes Endometrial Carcinoma Cell Growth. PLoS ONE 2013, 8, e69001. [CrossRef] [PubMed]

54. Flannery, C.A.; Saleh, F.L.; Choe, G.H.; Selen, D.J.; Kodaman, P.H.; Kliman, H.J.; Wood, T.L.; Taylor, H.S. Differential expression of IR-A, IR-B and IGF-1R in endometrial physiology and distinct signature in adenocarcinoma. J. Clin. Endocrinol. Metab. 2016, 101, 2883-2891. [CrossRef] [PubMed]

55. Bruchim, I.; Sarfstein, R.; Werner, H. The IGF hormonal network in endometrial cancer: Functions, regulation, and targeting approaches. Front. Endocrinol. Lausanne 2014, 5, 76. [CrossRef]

56. Djiogue, S.; Kamdje, A.H.N.; Vecchio, L.; Kipanyula, M.J.; Farahna, M.; Aldebasi, Y.; Etet, P.F.S. Insulin resistance and cancer: The role of insulin and IGFs. Endocr. Relat. Cancer 2013, 20, R1-R17. [CrossRef]

57. Petridou, E.; Koukoulomatis, P.; Alexe, D.M.; Voulgaris, Z.; Spanos, E.; Trichopoulos, D. Endometrial cancer and the IGF system: A case-control study in Greece. Oncology 2003, 64, 341-345. [CrossRef] 
58. Epaud, R.; Aubey, F.; Xu, J.; Chaker, Z.; Clemessy, M.; Dautin, A.; Ahamed, K.; Bonora, M.; Hoyeau, N.; Fléjou, J.F.; et al. Knockout of insulin-like growth factor-1 receptor impairs distal lung morphogenesis. PLOS ONE 2012, 7, e48071. [CrossRef]

59. Alvino, C.L.; Ong, S.C.; McNeil, K.A.; Delaine, C.; Booker, G.W.; Wallace, J.C.; Forbes, B.E. Understanding the mechanism of insulin and insulin-like growth factor (IGF) receptor activation by IGF-II. PLoS ONE 2011, 6, e27488. [CrossRef]

60. Wang, C.; Su, K.; Zhang, Y.; Zhang, W.; Zhao, Q.; Chu, D.; Guo, R. IR-A/IGF-1R-mediated signals promote epithelial-mesenchymal transition of endometrial carcinoma cells by activating PI3K/AKT and ERK pathways. Cancer Biol. Ther. 2019, 20, 295-306. [CrossRef]

61. Dai, C.; Li, N.; Song, G.; Yang, Y.; Ning, X. Insulin-like growth factor 1 regulates growth of endometrial carcinoma through PI3k signaling pathway in insulin-resistant type 2 diabetes. Am. J. Transl. Res. 2016, 8, 3329-3336.

62. Joehlin-Price, A.S.; Stephens, J.A.; Zhang, J.; Backes, F.J.; Cohn, D.E.; Suarez, A.A. Endometrial cancer insulin-like growth factor 1 receptor (IGF1R) expression increases with body mass index and is associated with pathologic extent and prognosis. Cancer Epidemiol. Biomark. Prev. 2016, 25, 438-445. [CrossRef] [PubMed]

63. Gunter, M.J.; Hoover, D.R.; Yu, H.; Wassertheil-Smoller, S.; Manson, J.E.; Li, J.; Harris, T.G.; Rohan, T.E.; Xue, X.N.; Ho, G.Y.F.; et al. A prospective evaluation of insulin and insulin-like growth factor-I as risk factors for endometrial cancer. Cancer Epidemiol. Biomark. Prev. 2008, 89, 921-929. [CrossRef] [PubMed]

64. Roy, R.N.; Gerulath, A.H.; Cecutti, A.; Bhavnani, B.R. Discordant expression of insulin-like growth factors and their receptor messenger ribonucleic acids in endometrial carcinomas relative to normal endometrium. Mol. Cell. Endocrinol. 1999, 153, 19-27. [CrossRef]

65. Ding, J.; Li, C.; Tang, J.; Yi, C.; Liu, J.Y.; Qiu, M. Higher Expression of Proteins in IGF/IR Axes in Colorectal Cancer is Associated with Type 2 Diabetes Mellitus. Pathol. Oncol. Res. 2016, 22, 773-779. [CrossRef]

66. Werner, H.; Sarfstein, R.; Bruchim, I. Investigational IGF1R inhibitors in early stage clinical trials for cancer therapy. Expert Opin. Investig. Drugs 2019, 28, 1101-1112. [CrossRef]

67. Cohen, D.H.; LeRoith, D. Obesity, type 2 diabetes, and cancer: The insulin and IGF connection. Endocr. Relat. Cancer 2012, 19, F25-F45. [CrossRef]

68. Sarfstein, R.; Friedman, Y.; Attias-Geva, Z.; Fishman, A.; Bruchim, I.; Werner, H. Metformin downregulates the insulin/IGF-I signaling pathway and inhibits different uterine serous carcinoma (USC) cells proliferation and migration in p53-dependent or -independent manners. PLoS ONE 2013, 8, e61537. [CrossRef]

69. Xie, W.; Li, T.; Yang, J.; Shang, M.; Xiao, Y.; Li, Q.; Yang, J. Metformin use and survival outcomes in endometrial cancer: A systematic review and meta-analysis. Oncotarget 2017, 8, 73079-73086. [CrossRef]

70. Chu, D.; Wu, J.; Wang, K.; Zhao, M.; Wang, C.; Li, L.; Guo, R. Effect of metformin use on the risk and prognosis of endometrial cancer: A systematic review and meta-analysis. BMC Cancer 2018, 18, 438. [CrossRef]

71. Guo, J.; Xu, K.; An, M.; Zhao, Y. Metformin and endometrial cancer survival: A quantitative synthesis of observational studies. Oncotarget 2017, 8, 66169-66177. [CrossRef]

72. Allard, J.B.; Duan, C. IGF-binding proteins: Why do they exist and why are there so many? Front. Endocrinol. Lausanne 2018, 9, 117. [CrossRef]

73. Rajwani, A.; Ezzat, V.; Smith, J.; Yuldasheva, N.Y.; Duncan, E.R.; Gage, M.; Cubbon, R.M.; Kahn, M.B.; Imrie, H.; Abbas, A.; et al. Increasing circulating IGFBP1 levels improves insulin sensitivity, promotes nitric oxide production, lowers blood pressure, and protects against atherosclerosis. Diabetes 2012, 61, 915-924. [CrossRef] [PubMed]

74. Poloz, Y.; Stambolic, V. Obesity and cancer, a case for insulin signaling. Cell Death Dis. 2015, 6, e2037. [CrossRef] [PubMed]

75. Weiderpass, E.; Brismar, K.; Bellocco, R.; Vainio, H.; Kaaks, R. Serum levels of insulin-like growth factor-I, IGF-binding protein 1 and 3, and insulin and endometrial cancer risk. Br. J. Cancer 2003, 89, 1697-1704. [CrossRef] [PubMed]

76. Russo, V.C.; Azar, W.J.; Yau, S.W.; Sabin, M.A.; Werther, G.A. IGFBP-2: The dark horse in metabolism and cancer. Cytokine Growth Factor Rev. 2015, 26, 329-346. [CrossRef] [PubMed]

77. Wheatcroft, S.B.; Kearney, M.T.; Shah, A.M.; Ezzat, V.A.; Miell, J.R.; Modo, M.; Williams, S.C.R.; Cawthorn, W.P.; Medina-Gomez, G.; Vidal-Puig, A.; et al. IGF-binding protein-2 protects against the development of obesity and insulin resistance. Diabetes 2007, 56, 285-294. [CrossRef] [PubMed] 
78. Yau, S.W.; Azar, W.J.; Sabin, M.A.; Werther, G.A.; Russo, V.C. IGFBP-2-Taking the lead in growth, metabolism and cancer. J. Cell Commun. Signal. 2015, 9, 125-142. [CrossRef] [PubMed]

79. Lee, E.J.; Mircean, C.; Shmulevich, I.; Wang, H.; Liu, J.; Niemistö, A.; Kavanagh, J.J.; Lee, J.H.; Zhang, W. Insulin-like growth factor binding protein 2 promotes ovarian cancer cell invasion. Mol. Cancer 2005, 4, 7. [CrossRef]

80. Guo, C.; Lu, H.; Gao, W.; Wang, L.; Lu, K.; Wu, S.; Pataer, A.; Huang, M.; El-Zein, R.; Lin, T.; et al. Insulin-like growth factor binding protein-2 level is increased in blood of lung cancer patients and associated with poor survival. PLoS ONE 2013, 8, e74973. [CrossRef]

81. Liu, H.; Li, L.; Chen, H.; Kong, R.; Pan, S.; Hu, J.; Wang, Y.; Li, Y.; Sun, B. Silencing IGFBP-2 decreases pancreatic cancer metastasis and enhances chemotherapeutic sensitivity. Oncotarget 2017, 8, 61674-61686. [CrossRef]

82. Liu, Y.; Song, C.; Shen, F.; Zhang, J.; Song, S.W. IGFBP2 promotes immunosuppression associated with its mesenchymal induction and Fc $\gamma$ RIIB phosphorylation in glioblastoma. PLoS ONE 2019, 14, e0222999. [CrossRef] [PubMed]

83. Pickard, A.; McCance, D.J. IGF-binding protein 2-Oncogene or tumor suppressor? Front. Endocrinol. Lausanne 2015, 6, 25. [CrossRef] [PubMed]

84. Jogie-Brahim, S.; Feldman, D.; Oh, Y. Unraveling insulin-like growth factor binding protein-3 actions in human disease. Endocr. Rev. 2009, 30, 417-437. [CrossRef]

85. Mochizuki, T.; Sakai, K.; Iwashita, M. Effects of insulin-like growth factor (IGF) binding protein-3 (IGFBP-3) on endometrial cancer (HHUA) cell apoptosis and EGF stimulated cell proliferation in vitro. Growth Horm. IGF Res. 2006, 16, 202-210. [CrossRef] [PubMed]

86. Wang, E.A.; Chen, W.Y.; Wong, C.H. Multiple growth factor targeting by engineered insulin-like rowth factor binding protein-3 augments EGF receptor tyrosine kinase inhibitor efficacy. Sci. Rep. 2020, 10, 2735. [CrossRef] [PubMed]

87. Groothuis, P.G.; Dassen, H.H.N.M.; Romano, A.; Punyadeera, C. Estrogen and the endometrium: Lessons learned from gene expression profiling in rodents and human. Hum. Reprod. Update 2007, 13, 405-417. [CrossRef]

88. Gupte, A.A.; Pownall, H.J.; Hamilton, D.J. Estrogen: An emerging regulator of insulin action and mitochondrial function. J. Diabetes Res. 2015, 2015, 916585. [CrossRef]

89. Barros, R.P.A.; Machado, U.F.; Warner, M.; Gustafsson, J.Å. Muscle GLUT4 regulation by estrogen receptors ER $\beta$ and ER $\alpha$. Proc. Natl. Acad. Sci. USA 2006, 103, 1605-1608. [CrossRef]

90. Rodriguez, A.C.; Blanchard, Z.; Maurer, K.A.; Gertz, J. Estrogen signaling in endometrial cancer: A key oncogenic pathway with several open questions. Horm. Cancer 2019, 10, 51-63. [CrossRef]

91. De Marco, P.; Cirillo, F.; Vivacqua, A.; Malaguarnera, R.; Belfiore, A.; Maggiolini, M. Novel aspects concerning the functional cross-talk between the insulin/IGF-I system and estrogen signaling in cancer cells. Front. Endocrinol. Lausanne 2015, 6, 30. [CrossRef]

92. Massarweh, S.; Osborne, C.K.; Creighton, C.J.; Qin, L.; Tsimelzon, A.; Huang, S.; Weiss, H.; Rimawi, M.; Schiff, R. Tamoxifen resistance in breast tumors is driven by growth factor receptor signaling with repression of classic estrogen receptor genomic function. Cancer Res. 2008, 68, 826-833. [CrossRef] [PubMed]

93. Lundholm, L.; Bryzgalova, G.; Gao, H.; Portwood, N.; Fält, S.; Berndt, K.D.; Dicker, A.; Galuska, D.; Zierath, J.R.; Gustafsson, J.Å.; et al. The estrogen receptor $\alpha$-selective agonist propyl pyrazole triol improves glucose tolerance in ob/ob mice; potential molecular mechanisms. J. Endocrinol. 2008, 199, 275-286. [CrossRef] [PubMed]

94. Yan, H.; Yang, W.; Zhou, F.; Li, X.; Pan, Q.; Shen, Z.; Han, G.; Newell-Fugate, A.; Tian, Y.; Majeti, R.; et al. Estrogen improves insulin sensitivity and suppresses gluconeogenesis via the transcription factor Foxo1. Diabetes 2019, 68, 291-304. [CrossRef]

95. Root-Bernstein, R.; Podufaly, A.; Dillon, P.F. Estradiol binds to insulin and insulin receptor decreasing insulin binding in vitro. Front. Endocrinol. Lausanne 2014, 5, 118. [CrossRef] [PubMed]

96. Tee, M.K.; Rogatsky, I.; Tzagarakis-Foster, C.; Cvoro, A.; An, J.; Christy, R.J.; Yamamoto, K.R.; Leitman, D.C. Estradiol and selective estrogen receptor modulators differentially regulate target genes with estrogen receptors $\alpha$ and $\beta$. Mol. Biol. Cell 2004, 15, 1262-1272. [CrossRef]

97. $\mathrm{Yu}, \mathrm{H}$. Role of the Insulin-Like Growth Factor Family in Cancer Development and Progression. J. Natl. Cancer Inst. 2000, 92, 1472-1489. [CrossRef] 
98. Merritt, M.A.; Strickler, H.D.; Einstein, M.H.; Yang, H.P.; Sherman, M.E.; Wentzensen, N.; Brouwer-Visser, J.; Cossio, M.J.; Whitney, K.D.; Yu, H.; et al. Insulin/IGF and sex hormone axes in human endometrium and associations with endometrial cancer risk factors. Cancer Causes Control. 2016, 27, 737-748. [CrossRef]

99. Ito, K.; Utsunomiya, H.; Yaegashi, N.; Sasano, H. Biological roles of estrogen and progesterone in human endometrial carcinoma-New developments in potential endocrine therapy for endometrial cancer. Endocr. J. 2007, 54, 667-679. [CrossRef]

100. Trabert, B.; Wentzensen, N.; Yang, H.P.; Sherman, M.E.; Hollenbeck, A.R.; Park, Y.; Brinton, L.A. Is estrogen plus progestin menopausal hormone therapy safe with respect to endometrial cancer risk? Int. J. Cancer 2013, 132, 417-426. [CrossRef]

101. Brinton, L.A.; Trabert, B.; Anderson, G.L.; Falk, R.T.; Felix, A.S.; Fuhrman, B.J.; Gass, M.L.; Kuller, L.H.; Pfeiffer, R.M.; Rohan, T.E.; et al. Serum estrogens and estrogen metabolites and endometrial cancer risk among postmenopausal women. Cancer Epidemiol. Biomark. Prev. 2016, 25, 1081-1089. [CrossRef]

102. Arcidiacono, B.; Iiritano, S.; Nocera, A.; Possidente, K.; Nevolo, M.T.; Ventura, V.; Foti, D.; Chiefari, E.; Brunetti, A. Insulin resistance and cancer risk: An overview of the pathogenetic mechanisms. Exp. Diabetes Res. 2012, 2012, 789174. [CrossRef]

103. Tian, W.; Teng, F.; Zhao, J.; Gao, J.; Gao, C.; Sun, D.; Liu, G.; Zhang, Y.; Yu, S.; Zhang, W.; et al. Estrogen and insulin synergistically promote type 1 endometrial cancer progression. Cancer Biol. Ther. 2017, 18, 1000-1010. [CrossRef]

104. Randolph, J.F.; Kipersztok, S.; Ayers, J.W.T.; Ansbacher, R.; Peegel, H.; Menon, K.M.J. The effect of insulin on aromatase activity in isolated human endometrial glands and stroma. Am. J. Obstet. Gynecol. 1987, 157, 1534-1539. [CrossRef]

105. Wolff, L.G.; Vassallo, J.; Pinto, C.B.; Yela, D.A.; Monteiro, I.U. Correlation between insulin resistance and steroid endometrial receptors, KI-67 and BCL-2 after menopause. Women's Health Sci. J. 2017, 1, 000104. [CrossRef]

106. Winters, S.J.; Gogineni, J.; Karegar, M.; Scoggins, C.; Wunderlich, C.A.; Baumgartner, R.; Ghooray, D.T. Sex hormone-binding globulin gene expression and insulin resistance. J. Clin. Endocrinol. Metab. 2014, 99, E2780-E2788. [CrossRef]

107. Gallagher, E.J.; LeRoith, D. The proliferating role of insulin and insulin-like growth factors in cancer. Trends Endocrinol. Metab. 2010, 21, 610-618. [CrossRef]

108. Makki, K.; Froguel, P.; Wolowczuk, I. Adipose tissue in obesity-related inflammation and insulin resistance: Cells, cytokines, and chemokines. ISRN Inflamm. 2013, 2013, 139239. [CrossRef]

109. Parida, S.; Siddharth, S.; Sharma, D. Adiponectin, obesity, and cancer: Clash of the bigwigs in health and disease. Int. J. Mol. Sci. 2019, 20, 2519. [CrossRef]

110. Prakash, J.; Mittal, B.; Awasthi, S.; Agarwal, C.G.; Srivastava, N. Hypoadiponectinemia in obesity: Association with insulin resistance. Indian J. Clin. Biochem. 2013, 28, 158-163. [CrossRef]

111. Gelsomino, L.; Naimo, G.D.; Catalano, S.; Mauro, L.; Andò, S. The emerging role of adiponectin in female malignancies. Int. J. Mol. Sci. 2019, 20, 2127. [CrossRef]

112. Cust, A.E.; Kaaks, R.; Friedenreich, C.; Bonnet, F.; Laville, M.; Lukanova, A.; Rinaldi, S.; Dossus, L.; Slimani, N.; Lundin, E.; et al. Plasma adiponectin levels and endometrial cancer risk in pre- and postmenopausal women. J. Clin. Endocrinol. Metab. 2007, 92, 255-263. [CrossRef] [PubMed]

113. Dal Maso, L.; Augustin, L.S.A.; Karalis, A.; Talamini, R.; Franceschi, S.; Trichopoulos, D.; Mantzoros, C.S.; La Vecchia, C. Circulating adiponectin and endometrial cancer risk. J. Clin. Endocrinol. Metab. 2004, 89, 1160-1163. [CrossRef] [PubMed]

114. Piya, M.K.; McTernan, P.G.; Kumar, S. Adipokine inflammation and insulin resistance: The role of glucose, lipids and endotoxin. J. Endocrinol. 2013, 216, T1-T15. [CrossRef] [PubMed]

115. Hedbacker, K.; Birsoy, K.; Wysocki, R.W.; Asilmaz, E.; Ahima, R.S.; Farooqi, I.S.; Friedman, J.M. Antidiabetic effects of IGFBP2, a leptin-regulated gene. Cell Metab. 2010, 11, 11-22. [CrossRef] [PubMed]

116. Neumann, U.H.; Chen, S.; Tam, Y.Y.C.; Baker, R.K.; Covey, S.D.; Cullis, P.R.; Kieffer, T.J. IGFBP2 is neither sufficient nor necessary for the physiological actions of leptin on glucose homeostasis in male ob/ob mice. Endocrinology 2014, 155, 716-725. [CrossRef] [PubMed]

117. Osegbe, I.; Okpara, H.; Azinge, E. Relationship between serum leptin and insulin resistance among obese Nigerian women. Ann. Afr. Med. 2016, 15, 14-19. [CrossRef] 
118. Wang, T.N.; Chang, W.T.; Chiu, Y.W.; Lee, C.Y.; Lin, K.D.; Cheng, Y.Y.; Su, Y.J.; Chung, H.F.; Huang, M.C. Relationships between changes in leptin and insulin resistance levels in obese individuals following weight loss. Kaohsiung J. Med. Sci. 2013, 29, 436-443. [CrossRef]

119. Zuo, H.; Shi, Z.; Yuan, B.; Dai, Y.; Wu, G.; Hussain, A. Association between serum leptin concentrations and insulin resistance: A population-based study from China. PLoS ONE 2013, 8, e54615. [CrossRef]

120. Ding, S.; Madu, C.O.; Lu, Y. The impact of hormonal imbalances associated with obesity on the incidence of endometrial cancer in postmenopausal women. J. Cancer 2020, 11, 5456-5465. [CrossRef]

121. Schmandt, R.E.; Iglesias, D.A.; Co, N.N.; Lu, K.H. Understanding obesity and endometrial cancer risk: Opportunities for prevention. Am. J. Obstet. Gynecol. 2011, 205, 518-525. [CrossRef]

122. Wang, J.; Obici, S.; Morgan, K.; Barzilai, N.; Feng, Z.; Rossetti, L. Overfeeding rapidly induces leptin and insulin resistance. Diabetes 2001, 50, 2786-2791. [CrossRef]

123. Uzan, J.; Laas, E.; Alsamad, I.A.; Skalli, D.; Mansouri, D.; Haddad, B.; Touboul, C. Supervised clustering of adipokines and hormonal receptors predict prognosis in a population of obese women with type 1 endometrial cancer. Int. J. Mol. Sci. 2017, 185, 1055. [CrossRef]

124. Lin, T.; Zhao, X.; Kong, W.M. Association between adiponectin levels and endometrial carcinoma risk: Evidence from a dose-response meta-analysis. BMJ Open 2015, 5, e008541. [CrossRef]

125. Gong, T.T.; Wu, Q.J.; Wang, Y.L.; Ma, X.X. Circulating adiponectin, leptin and adiponectin-leptin ratio and endometrial cancer risk: Evidence from a meta-analysis of epidemiologic studies. Int. J. Cancer 2015, 137, 1967-1978. [CrossRef]

126. Ma, Y.; Liu, Z.; Zhang, Y.; Lu, B. Serum leptin, adiponectin and endometrial cancer risk in Chinese women. J. Gynecol. Oncol. 2013, 24, 336-341. [CrossRef]

127. Busch, E.L.; Crous-Bou, M.; Prescott, J.; Downing, M.J.; Rosner, B.A.; Mutter, G.L.; De Vivo, I. Adiponectin, leptin, and insulin-pathway receptors as endometrial cancer subtyping markers. Horm. Cancer 2018, 9, 33-39. [CrossRef]

128. Hebbard, L.; Ranscht, B. Multifaceted roles of Adiponectin in cancer. Best Pract. Res. Clin. Endocrinol. Metab. 2014, 28, 56-59. [CrossRef]

129. VanSaun, M.N. Molecular pathways: Adiponectin and leptin signaling in cancer. Clin. Cancer Res. 2013, 19, 1926-1932. [CrossRef]

130. Tumminia, A.; Vinciguerra, F.; Parisi, M.; Graziano, M.; Sciacca, L.; Baratta, R.; Frittitta, L. Adipose tissue, obesity and adiponectin: Role in endocrine cancer risk. Int. J. Mol. Sci. 2019, 20, 2863. [CrossRef]

131. Ilhan, T.T.; Kebapcilar, A.; Yilmaz, S.A.; Ilhan, T.; Kerimoglu, O.S.; Pekin, A.T.; Akyurek, F.; Unlu, A.; Celik, C. Relations of serum visfatin and resistin levels with endometrial cancer and factors associated with its prognosis. Asian Pac. J. Cancer Prev. 2015, 16, 4503-4508. [CrossRef]

132. Hlavna, M.; Kohut, L.; Lipkova, J.; Bienertova-Vasku, J.; Dostalova, Z.; Chovanec, J.; Vasku, A. Relationship of resistin levels with endometrial cancer risk. Neoplasma 2011, 58, 124-128. [CrossRef] [PubMed]

133. Rabe, K.; Lehrke, M.; Parhofer, K.G.; Broedl, U.C. Adipokines and insulin resistance. Mol. Med. 2008, 14, 741-751. [CrossRef] [PubMed]

134. Catalanotto, C.; Cogoni, C.; Zardo, G. MicroRNA in control of gene expression: An overview of nuclear functions. Int. J. Mol. Sci. 2016, 17, 1712. [CrossRef] [PubMed]

135. O’Brien, J.; Hayder, H.; Zayed, Y.; Peng, C. Overview of microRNA biogenesis, mechanisms of actions, and circulation. Front. Endocrinol. Lausanne 2018, 9, 402. [CrossRef] [PubMed]

136. Nigi, L.; Grieco, G.E.; Ventriglia, G.; Brusco, N.; Mancarella, F.; Formichi, C.; Dotta, F.; Sebastiani, G. MicroRNAs as regulators of insulin signaling: Research updates and potential therapeutic perspectives in type 2 diabetes. Int. J. Mol. Sci. 2018, 19, 3705. [CrossRef]

137. Khan, S.; Wang, C.H. ER stress in adipocytes and insulin resistance: Mechanisms and significance (Review). Mol. Med. Rep. 2014, 10, 2234-2240. [CrossRef]

138. Wang, J.; Chen, J.; Sen, S. MicroRNA as Biomarkers and Diagnostics. J. Cell. Physiol. 2016, 231, 25-30. [CrossRef]

139. La Ferlita, A.; Battaglia, R.; Andronico, F.; Caruso, S.; Cianci, A.; Purrello, M.; Di Pietro, C. Non-coding RNAs in endometrial physiopathology. Int. J. Mol. Sci. 2018, 19, 2120. [CrossRef]

140. Martello, G.; Rosato, A.; Ferrari, F.; Manfrin, A.; Cordenonsi, M.; Dupont, S.; Enzo, E.; Guzzardo, V.; Rondina, M.; Spruce, T.; et al. A microRNA targeting dicer for metastasis control. Cell 2010, 141, 1195-1207. [CrossRef] 
141. Wang, Q.; Xu, K.; Tong, Y.; Dai, Z.; Xu, T.; He, D.; Ying, J. Novel miRNA markers for the diagnosis and prognosis of endometrial cancer. J. Cell. Mol. Med. 2020, 24, 4533-4546. [CrossRef]

142. Ratner, E.S.; Tuck, D.; Richter, C.; Nallur, S.; Patel, R.M.; Schultz, V.; Hui, P.; Schwartz, P.E.; Rutherford, T.J.; Weidhaas, J.B. MicroRNA signatures differentiate uterine cancer tumor subtypes. Gynecol. Oncol. 2010, 118, 251-257. [CrossRef] [PubMed]

143. Kalinkova, L.; Kajo, K.; Karhanek, M.; Wachsmannova, L.; Suran, P.; Zmetakova, I.; Fridrichova, I. Discriminating miRNA profiles between endometrioid well- and poorly-differentiated tumours and endometrioid and serous subtypes of endometrial cancers. Int. J. Mol. Sci. 2020, 21, 6071. [CrossRef] [PubMed]

144. Chung, T.K.H.; Cheung, T.H.; Huen, N.Y.; Wong, K.W.Y.; Lo, K.W.K.; Yim, S.F.; Siu, N.S.S.; Wong, Y.M.; Tsang, P.T.; Pang, M.W.; et al. Dysregulated microRNAs and their predicted targets associated with endometrioid endometrial adenocarcinoma in Hong Kong women. Int. J. Cancer 2009, 124, 1358-1365. [CrossRef] [PubMed]

145. Hiroki, E.; Akahira, J.I.; Suzuki, F.; Nagase, S.; Ito, K.; Suzuki, T.; Sasano, H.; Yaegashi, N. Changes in microRNA expression levels correlate with clinicopathological features and prognoses in endometrial serous adenocarcinomas. Cancer Sci. 2010, 101, 241-249. [CrossRef]

146. Jia, W.; Wu, Y.; Zhang, Q.; Gao, G.; Zhang, C.; Xiang, Y. Identification of four serum microRNAs from a genome-wide serum microRNA expression profile as potential non-invasive biomarkers for endometrioid endometrial cancer. Oncol. Lett. 2013, 6, 261-267. [CrossRef]

147. Montagnana, M.; Benati, M.; Danese, E.; Giudici, S.; Perfranceschi, M.; Ruzzenenete, O.; Salvagno, G.L.; Bassi, A.; Gelati, M.; Paviati, E.; et al. Aberrant microRNA epression in patients with endometrial cancer. Int. J. Gynecol. Cancer 2017, 27, 459-466. [CrossRef]

148. Devor, E.J.; Hovey, A.M.; Goodheart, M.J.; Ramachandran, S.; Leslie, K.K. MicroRNA expression profiling of endometrial endometrioid adenocarcinomas and serous adenocarcinomas reveals profiles containing shared, unique and differentiating groups of microRNAs. Oncol. Rep. 2011, 26, 995-1002. [CrossRef]

149. Cohn, D.E.; Fabbri, M.; Valeri, N.; Alder, H.; Ivanov, I.; Liu, C.G.; Croce, C.M.; Resnick, K.E. Comprehensive miRNA profiling of surgically staged endometrial cancer. Am. J. Obstet. Gynecol. 2010, 202, 656.e1-656.e8. [CrossRef]

150. Wu, Y.S.; Lin, H.; Chen, D.; Yi, Z.; Zeng, B.; Jiang, Y.; Ren, G. A four-miRNA signature as a novel biomarker for predicting survival in endometrial cancer. Gene 2019, 697, 86-93. [CrossRef]

151. Donkers, H.; Bekkers, R.; Galaal, K. Diagnostic value of microRNA panel in endometrial cancer: A systematic review. Oncotarget 2020, 11, 2010-2023. [CrossRef]

152. Zhu, H.; Ng, S.C.; Segr, A.V.; Shinoda, G.; Shah, S.P.; Einhorn, W.S.; Takeuchi, A.; Engreitz, J.M.; Hagan, J.P.; Kharas, M.G.; et al. The Lin28/let-7 axis regulates glucose metabolism. Cell 2011, 147, 81-94. [CrossRef] [PubMed]

153. Liu, P.; Qi, M.; Ma, C.; Lao, G.; Liu, Y.; Liu, Y.; Liu, Y. Let7a inhibits the growth of endometrial carcinoma cells by targeting Aurora-B. FEBS Lett. 2013, 587, 2523-2529. [CrossRef] [PubMed]

154. Chirshev, E.; Oberg, K.C.; Ioffe, Y.J.; Unternaehrer, J.J. Let-7 as biomarker, prognostic indicator, and therapy for precision medicine in cancer. Clin. Transl. Med. 2019, 8, 24. [CrossRef] [PubMed]

155. Myatt, S.S.; Wang, J.; Monteiro, L.J.; Christian, M.; Ho, K.-K.; Fusi, L.; Dina, R.E.; Brosens, J.J.; Ghaem-Maghami, S.; Lam, E.W.-F. Repression of FOXO1 expression by microRNAs in endometrial cancer. Cancer Res. 2010, 70, 367-377. [CrossRef] [PubMed]

156. Ramachandran, D.; Roy, U.; Garg, S.; Ghosh, S.; Pathak, S.; Kolthur-Seetharam, U. Sirt1 and mir-9 expression is regulated during glucose-stimulated insulin secretion in pancreatic $\beta$-islets. FEBS J. 2011, 287, 1167-1174. [CrossRef]

157. Wu, P.; Wang, Q.; Jiang, C.; Chen, C.; Liu, Y.; Chen, Y.; Zeng, Y. MicroRNA-29a is involved lipid metabolism dysfunction and insulin resistance in C2C12 myotubes by targeting PPAR $\delta$. Mol. Med. Rep. 2018, 17, 8493-8501. [CrossRef]

158. Jiang, T.; Sui, D.; You, D.; Yao, S.; Zhang, L.; Wang, Y.; Zhao, J.; Zhang, Y. MiR-29a-5p inhibits proliferation and invasion and induces apoptosis in endometrial carcinoma via targeting TPX2. Cell Cycle 2018, 17, 1268-1278. [CrossRef] [PubMed] 
159. He, A.; Zhu, L.; Gupta, N.; Chang, Y.; Fang, F. Overexpression of micro ribonucleic acid 29, highly up-regulated in diabetic rats, leads to insulin resistance in 3T3-L1 adipocytes. Mol. Endocrinol. 2007, 21, 2785-2794. [CrossRef]

160. Chen, H.X.; Xu, X.X.; Tan, B.Z.; Zhang, Z.; Zhou, X.D. MicroRNA-29b inhibits angiogenesis by targeting VEGFA through the MAPK/ERK and PI3K/Akt signaling pathways in endometrial carcinoma. Cell. Physiol. Biochem. 2017, 41, 933-946. [CrossRef]

161. Kong, J.; He, X.; Wang, Y.; Li, J. Effect of microRNA-29b on proliferation, migration, and invasion of endometrial cancer cells. J. Int. Med. Res. 2019, 47, 3803-3817. [CrossRef]

162. Massart, J.; Sjögren, R.J.O.; Lundell, L.S.; Mudry, J.M.; Franck, N.; O'Gorman, D.J.; Egan, B.; Zierath, J.R.; Krook, A. Altered miR-29 expression in type 2 diabetes influences glucose and lipid metabolism in skeletal muscle. Diabetes 2017, 66, 1807-1818. [CrossRef]

163. van Sinderen, M.; Griffiths, M.; Menkhorst, E.; Niven, K.; Dimitriadis, E. Restoration of microRNA-29c in type I endometrioid cancer reduced endometrial cancer cell growth. Oncol. Lett. 2019, 18, 2684-2693. [CrossRef] [PubMed]

164. Yu, D.; Zhou, H.; Xun, Q.; Xu, X.; Ling, J.; Hu, Y. microRNA-103 regulates the growth and invasion of endometrial cancer cells through the downregulation of tissue inhibitor of metalloproteinase 3. Oncol. Lett. 2012, 3, 1221-1226. [CrossRef]

165. Trajkovski, M.; Hausser, J.; Soutschek, J.; Bhat, B.; Akin, A.; Zavolan, M.; Heim, M.H.; Stoffel, M. MicroRNAs 103 and 107 regulate insulin sensitivity. Nature 2011, 474, 649-654. [CrossRef] [PubMed]

166. Bao, W.; Zhang, Y.; Li, S.; Fan, Q.; Qiu, M.; Wang, Y.; Li, Y.; Ji, X.; Yang, Y.; Sang, Z.; et al. MiR-107-5p promotes tumor proliferation and invasion by targeting estrogen receptor- $\alpha$ in endometrial carcinoma. Oncol. Rep. 2019, 41, 1575-1585. [CrossRef]

167. Ryu, H.S.; Park, S.Y.; Ma, D.; Zhang, J.; Lee, W. The induction of microrna targeting IRS-1 is involved in the development of insulin resistance under conditions of mitochondrial dysfunction in hepatocytes. PLoS ONE 2011, 6, e17343. [CrossRef]

168. Zhao, X.; Zhu, D.; Lu, C.; Yan, D.; Li, L.; Chen, Z. MicroRNA-126 inhibits the migration and invasion of endometrial cancer cells by targeting insulin receptor substrate 1. Oncol. Lett. 2016, 11, 1207-1212. [CrossRef]

169. Liu, Y.; Hua, T.; Chi, S.; Wang, H. Identification of key pathways and genes in endometrial cancer using bioinformatics analyses. Oncol. Lett. 2019, 17, 897-906. [CrossRef]

170. Yu, X.; Zhong, L. Pioglitazone/microRNA-141/FOXA2: A novel axis in pancreatic $\beta$-cells proliferation and insulin secretion. Mol. Med. Rep. 2018, 17, 7931-7938. [CrossRef]

171. Yoneyama, K.; Ishibashi, O.; Kawase, R.; Kurose, K.; Takeshita, T. MiR-200a, miR-200b and miR-429 are onco-miRs that target the PTEN gene in endometrioid endometrial carcinoma. Anticancer Res. 2015, 35, 1401-1410.

172. Filios, S.R.; Xu, G.; Chen, J.; Hong, K.; Jing, G.; Shalev, A. MicroRNA-200 is induced by thioredoxin-interacting protein and regulates Zeb1 protein signaling and beta cell. J. Biol. Chem. 2014, 289, 36275-36283. [CrossRef] [PubMed]

173. Peng, J.; Zhou, Y.; Deng, Z.; Zhang, H.; Wu, Y.; Song, T.; Yang, Y.; Wei, H.; Peng, J. miR-221 negatively regulates inflammation and insulin sensitivity in white adipose tissue by repression of sirtuin-1 (SIRT1). J. Cell. Biochem. 2018, 119, 6418-6428. [CrossRef] [PubMed]

174. Penolazzi, L.; Bonaccorsi, G.; Gafà, R.; Ravaioli, N.; Gabriele, D.; Bosi, C.; Lanza, G.; Greco, P.; Piva, R. SLUG/HIF1- $\alpha /$ miR-221 regulatory circuit in endometrial cancer. Gene 2019, 711, 143938. [CrossRef] [PubMed]

175. Ono, K.; Igata, M.; Kondo, T.; Kitano, S.; Takaki, Y.; Hanatani, S.; Sakaguchi, M.; Goto, R.; Senokuchi, T.; Kawashima, J.; et al. Identification of microRNA that represses IRS-1 expression in liver. PLoS ONE 2018, 13, e0191553. [CrossRef]

176. Liu, B.; Che, Q.; Qiu, H.; Bao, W.; Chen, X.; Lu, W.; Li, B.; Wan, X. Elevated miR-222-3p promotes proliferation and invasion of endometrial carcinoma via targeting ER $\alpha$. PLOS ONE 2014, 9, e87563. [CrossRef]

177. Shu, S.; Liu, X.; Xu, M.; Gao, X.; Chen, S.; Zhang, L.; Li, R. MicroRNA-320a acts as a tumor suppressor in endometrial carcinoma by targeting IGF-1R. Int. J. Mol. Med. 2019, 43, 1505-1512. [CrossRef]

178. Ling, H.Y.; Ou, H.S.; Feng, S.D.; Zhang, X.Y.; Tuo, Q.H.; Chen, L.X.; Zhu, B.Y.; Gao, Z.P.; Tang, C.K.; Yin, W.D.; et al. Changes in microrna (mir) profile and effects of mir-320 in insulin-resistant 3t3-11 adipocytes. Clin. Exp. Pharmacol. Physiol. 2009, 36, e32-e39. [CrossRef] 
179. Jayaraman, M.; Radhakrishnan, R.; Mathews, C.A.; Yan, M.; Husain, S.; Moxley, K.M.; Song, Y.S.; Dhanasekaran, D.N. Identification of novel diagnostic and prognostic miRNA signatures in endometrial cancer. Genes Cancer 2017, 8, 566-576. [CrossRef]

180. Cinkornpumin, J.; Roos, M.; Nguyen, L.; Liu, X.; Gaeta, X.; Lin, S.; Chan, D.N.; Liu, A.; Gregory, R.I.; Jung, M.; et al. A small molecule screen to identify regulators of let-7 targets. Sci. Rep. 2017, 7, 15973. [CrossRef]

181. Frost, R.J.A.; Olson, E.N. Control of glucose homeostasis and insulin sensitivity by the Let-7 family of microRNAs. Proc. Natl. Acad. Sci. USA 2011, 108, 21075-21080. [CrossRef]

182. Zhang, B.H.; Shen, C.A.; Zhu, B.W.; An, H.Y.; Zheng, B.; Xu, S.B.; Sun, J.C.; Sun, P.C.; Zhang, W.; Wang, J.; et al. Insight into miRNAs related with glucometabolic disorder. Biomed. Pharmacother. 2019, 111, 657-665. [CrossRef] [PubMed]

183. Jiang, S. A regulator of metabolic reprogramming: MicroRNA Let-7. Transl. Oncol. 2019, 12, 1005-1013. [CrossRef] [PubMed]

184. Delangle, R.; De Foucher, T.; Larsen, A.K.; Sabbah, M.; Azaïs, H.; Bendifallah, S.; Daraï, E.; Ballester, M.; Mehats, C.; Uzan, C.; et al. The use of microRNAs in the management of endometrial cancer: A meta-analysis. Cancers 2019, 11, 832. [CrossRef]

185. Srivastava, S.K.; Ahmad, A.; Zubair, H.; Miree, O.; Singh, S.; Rocconi, R.P.; Scalici, J.; Singh, A.P. MicroRNAs in gynecological cancers: Small molecules with big implications. Cancer Lett. 2017, 407, 123-138. [CrossRef] [PubMed]

186. Jurcevic, S.; Olsson, B.; Klinga-Levan, K. MicroRNA expression in human endometrial adenocarcinoma. Cancer Cell Int. 2014, 14, 88. [CrossRef]

187. Zhang, Y.; Zhang, L.; Sun, H.; Lv, Q.; Qiu, C.; Che, X.; Liu, Z.; Jiang, J. Forkhead transcription factor 1 inhibits endometrial cancer cell proliferation via sterol regulatory element-binding protein 1. Oncol. Lett. 2017, 13, 731-737. [CrossRef]

188. Wang, Y.; Zhang, L.; Che, X.; Li, W.; Liu, Z.; Jiang, J. Roles of SIRT1/FoxO1/SREBP-1 in the development of progestin resistance in endometrial cancer. Arch. Gynecol. Obstet. 2018, 298, 961-969. [CrossRef]

189. Plaisance, V.; Abderrahmani, A.; Perret-Menoud, V.; Jacquemin, P.; Lemaigre, F.; Regazzi, R. MicroRNA-9 controls the expression of Granuphilin/Slp4 and the secretory response of insulin-producing cells. J. Biol. Chem. 2006, 281, 26932-26942. [CrossRef]

190. Nowek, K.; Wiemer, E.A.C.; Jongen-Lavrencic, M. The versatile nature of miR-9/9* in human cancer. Oncotarget 2018, 9, 20838-20854. [CrossRef]

191. Slusarz, A.; Pulakat, L. The two faces of miR-29. J. Cardiovasc. Med. 2015, 16, 480-490. [CrossRef]

192. Yu-Han, H.; Kanke, M.; Kurtz, C.L.; Cubitt, R.; Bunaciu, R.P.; Miao, J.; Zhou, L.; Graham, J.L.; Hussain, M.M.; Havel, P.; et al. Acute suppression of insulin resistance-associated hepatic miR-29 in vivo improves glycemic control in adult mice. Physiol. Genom. 2019, 51, 379-389. [CrossRef]

193. Kwon, J.J.; Factora, T.D.; Dey, S.; Kota, J. A systematic review of miR-29 in cancer. Mol. Ther. Oncolytics 2019, 12, 173-194. [CrossRef] [PubMed]

194. Jiang, H.; Zhang, G.; Wu, J.H.; Jiang, C.P. Diverse roles of miR-29 in cancer (Review). Oncol. Rep. 2014, 31, 1509-1516. [CrossRef] [PubMed]

195. Du, J.; Zhang, F.; Zhang, L.; Jia, Y.; Chen, H. MicroRNA-103 regulates the progression in endometrial carcinoma through ZO-1. Int. J. Immunopathol. Pharmacol. 2019, 33, 1-8. [CrossRef] [PubMed]

196. Snowdon, J.; Zhang, X.; Childs, T.; Tron, V.A.; Feilotter, H. The microRNA-200 family is upregulated in endometrial carcinoma. PLoS ONE 2011, 6, e22828. [CrossRef] [PubMed]

197. Belgardt, B.F.; Ahmed, K.; Spranger, M.; Latreille, M.; Denzler, R.; Kondratiuk, N.; Von Meyenn, F.; Villena, F.N.; Herrmanns, K.; Bosco, D.; et al. The microRNA-200 family regulates pancreatic beta cell survival in type 2 diabetes. Nat. Med. 2015, 21, 619-627. [CrossRef]

198. Magenta, A.; Ciarapica, R.; Capogrossi, M.C. The emerging role of miR-200 family in cardiovascular diseases. Circ. Res. 2017, 120, 1399-1402. [CrossRef]

199. Lu, J.; Zhang, X.; Zhang, R.; Ge, Q. MicroRNA heterogeneity in endometrial cancer cell lines revealed by deep sequencing. Oncol. Lett. 2015, 6, 3457-3465. [CrossRef]

200. Panda, H.; Pelakh, L.; Chuang, T.D.; Luo, X.; Bukulmez, O.; Chegini, N. Endometrial miR-200c is altered during transformation into cancerous states and targets the expression of ZEBs, VEGFA, FLT1, IKK $\beta$, KLF9, and FBLN5. Reprod. Sci. 2012, 19, 786-796. [CrossRef] 
201. Liu, Y.; El-Naggar, S.; Darling, D.S.; Higashi, Y.; Dean, D.C. Zeb1 links epithelial-mesenchymal transition and cellular senescence. Development 2008, 135, 579-588. [CrossRef]

202. Wellner, U.; Schubert, J.; Burk, U.C.; Schmalhofer, O.; Zhu, F.; Sonntag, A.; Waldvogel, B.; Vannier, C.; Darling, D.; Zur Hausen, A.; et al. The EMT-activator ZEB1 promotes tumorigenicity by repressing stemness-inhibiting microRNAs. Nat. Cell Biol. 2009, 11, 1487-1495. [CrossRef] [PubMed]

203. Tang, Y.; Shu, G.; Yuan, X.; Jing, N.; Song, J. FOXA2 functions as a suppressor of tumor metastasis by inhibition of epithelial-to-mesenchymal transition in human lung cancers. Cell Res. 2011, 21, 316-326. [CrossRef] [PubMed]

204. Bach, D.H.; Long, N.P.; Luu, T.T.T.; Anh, N.H.; Kwon, S.W.; Lee, S.K. The dominant role of forkhead box proteins in cancer. Int. J. Mol. Sci. 2018, 19, 3279. [CrossRef] [PubMed]

205. Ramón, L.A.; Braza-Boïls, A.; Gilabert, J.; Chirivella, M.; España, F.; Estellés, A.; Gilabert-Estellés, J. MicroRNAs related to angiogenesis are dysregulated in endometrioid endometrial cancer. Hum. Reprod. 2012, 27, 3036-3045. [CrossRef] [PubMed]

206. Meerson, A.; Traurig, M.; Ossowski, V.; Fleming, J.M.; Mullins, M.; Baier, L.J. Human adipose microRNA-221 is upregulated in obesity and affects fat metabolism downstream of leptin and TNF- $\alpha$. Diabetologia 2013, 56, 1971-1979. [CrossRef]

207. Abbas, A.; Imrie, H.; Viswambharan, H.; Sukumar, P.; Rajwani, A.; Cubbon, R.M.; Gage, M.; Smith, J.; Galloway, S.; Yuldeshava, N.; et al. The insulin-like growth factor-1 receptor is a negative regulator of nitric oxide bioavailability and insulin sensitivity in the endothelium. Diabetes 2011, 60, 2169-2178. [CrossRef]

208. Jasinski-Bergner, S.; Kielstein, H. Adipokines regulate the expression of tumor-relevant microRNAs. Obes. Facts 2019, 12, 211-225. [CrossRef]

209. Thomou, T.; Mori, M.A.; Dreyfuss, J.M.; Konishi, M.; Sakaguchi, M.; Wolfrum, C.; Rao, T.N.; Winnay, J.N.; Garcia-Martin, R.; Grinspoon, S.K.; et al. Adipose-derived circulating miRNAs regulate gene expression in other tissues. Nature 2017, 542, 450-455. [CrossRef]

210. Withers, S.B.; Dewhurst, T.; Hammond, C.; Topham, C.H. MiRNAs as novel adipokines: Obesity-related circulating MiRNAs influence chemosensitivity in cancer patients. Non-Coding RNA 2020, 6, 5. [CrossRef]

211. Ge, Q.; Brichard, S.; Yi, X.; Li, Q. MicroRNAs as a new mechanism regulating adipose tissue inflammation in obesity and as a novel therapeutic strategy in the metabolic syndrome. J. Immunol. Res. 2014, 2014, 987285. [CrossRef]

212. Valadi, H.; Ekström, K.; Bossios, A.; Sjöstrand, M.; Lee, J.J.; Lötvall, J.O. Exosome-mediated transfer of mRNAs and microRNAs is a novel mechanism of genetic exchange between cells. Nat. Cell Biol. 2007, 9, 654-659. [CrossRef] [PubMed]

213. Constantine, G.D.; Kessler, G.; Graham, S.; Goldstein, S.R. Increased incidence of endometrial cancer following the women's health initiative: An assessment of risk factors. J. Women's Health 2019, 28, 237-243. [CrossRef] [PubMed]

214. Hernandez, A.V.; Pasupuleti, V.; Benites-Zapata, V.A.; Thota, P.; Deshpande, A.; Perez-Lopez, F.R. Insulin resistance and endometrial cancer risk: A systematic review and meta-analysis. Eur. J. Cancer 2015, 51, 2747-2758. [CrossRef] [PubMed]

(C) 2020 by the authors. Licensee MDPI, Basel, Switzerland. This article is an open access article distributed under the terms and conditions of the Creative Commons Attribution (CC BY) license (http://creativecommons.org/licenses/by/4.0/). 